\title{
28. SEISMIC FACIES OF THE MADEIRA ABYSSAL PLAIN: A CORRELATION BETWEEN SEISMIC REFLECTION PROFILE AND BOREHOLE DATA ${ }^{1}$
}

\author{
R.G. Rothwell, ${ }^{2}$ B. Alibés ${ }^{3}$ and P.P.E. Weaver ${ }^{2}$
}

\begin{abstract}
Seismic profiles across the Madeira Abyssal Plain show a relatively simple seismic stratigraphy in which an irregular diffractive acoustic basement is overlain by distinctive seismic units, reflecting a great thickness of ponded turbidites overlying pelagic drape. Within the uppermost ponded turbidite unit, a number of distinct, continuous, and laterally extensive reflectors are recognized. Sites 950 through 952 were drilled into these reflectors and allow dating of the beginning of large-scale turbidite emplacement on the abyssal plain and identification and dating of previously recognized seismic reflectors with a good degree of certainty. The extent and probable volume of the distinct turbidite packages can now be quantified.

The Madeira Abyssal Plain overlies oceanic crust of Cretaceous age. Five distinct seismic units, separated by prominent, continuous, laterally extensive reflectors, can be identified. The lowermost of these (Unit B), which directly overlies acoustic basement, is a variably stratified unit and contains reflectors that generally show low coherency and onlap onto basement highs. At Site 950, the upper part of Unit B consists of red pelagic clays, with thin calcareous turbidites and ash layers, of late Eocene to Oligocene age. Unit A overlies Unit B with clear unconformity, marked by a conspicuous basinwide seismic reflector (Reflector 4). Unit A is a variably stratified unit and can be divided into four seismic units, A0 through A3, separated by prominent reflectors of regional extent. These units consist of thick, ponded turbidites with pelagic intervals. Many turbidites are basinwide in extent and can be correlated between drill sites. Four main types of turbidites are recognized: volcanic-rich turbidites derived from the Canary Islands, organic-rich turbidites derived from the Northwest African Margin, calcareous turbidites derived from seamounts to the west of the plain, and turbidites of "intermediate" character. Organic-rich turbidites are the dominant type, although volcanic-rich turbidites are numerous in Units A0 through A2. Conversion of two-way traveltime to depth using shipboard sonic log data suggests that thick volcanic-rich and "intermediate" character turbidites of wide lateral extent commonly correspond to strong seismic reflectors, and that acoustically transparent intervals within Unit A correspond to intervals of predominantly organic-rich turbidites. The base of Unit A is the regionally important Reflector 4 that correlates with a distinctive calcareous bed at all three drill sites dated at $16 \mathrm{Ma}$. The seismic units can be laterally mapped using an extensive data set of seismic reflection profiles and the minimum volumes of sediments deposited within individual seismic units calculated, giving values for sediment accumulation on the plain per unit time. The data show that since the inception of the abyssal plain in the middle Miocene (16 Ma), a minimum of $19,000 \mathrm{~km}^{3}$ of sediments (turbidites and hemipelagites) have been deposited.
\end{abstract}

\section{INTRODUCTION}

The Madeira Abyssal Plain lies in the center of the Canary Basin, $1000 \mathrm{~km}$ from the Northwest African Margin (Fig. 1). The late Quaternary sediments (back to $300 \mathrm{ka}$ ) have been intensively studied over the past $15 \mathrm{yr}$ through an extensive piston coring program (Weaver and Rothwell, 1987; Rothwell et al., 1992; Weaver et al., 1992), initially because of its selection by the "Seabed Working Group" of the Organization for Economic Cooperation and Development's Nuclear Energy Agency (NEA) as a possible site for the deep-sea disposal of radioactive waste (Anderson, 1980). A small number of long piston cores, collected as part of the same program, have allowed the study of sedimentation patterns back to $730 \mathrm{ka}$ (Schuttenhelm et al., 1989).

The abyssal plain sediments consist of a sequence of thin to very thick structureless muds, sometimes underlain by thin, commonly laminated, silty muds interbedded with thin bioturbated marls and clays (Weaver and Rothwell, 1987). The thin to very thick structureless muds were deposited by turbidity currents from three main sources: the flanks of the volcanic Canary Islands and, possibly,

${ }^{1}$ Weaver, P.P.E., Schmincke, H.-U., Firth, J.V., and Duffield, W. (Eds.), 1998. Proc. ODP, Sci. Results, 157: College Station, TX (Ocean Drilling Program).

${ }^{2}$ Southampton Oceanography Centre, Empress Dock, Southampton, SO14 3ZH, United Kingdom. R.G.Rothwell@soc.soton.ac.uk

${ }^{3}$ UA Geociencias Marinas CSIC-UB; GRC Geociències Marines, Dep. Geologia Dinàmica, Geofísica i P., Universitat de Barcelona, Campus de Pedralbes, 08071 Barcelona, Spain.

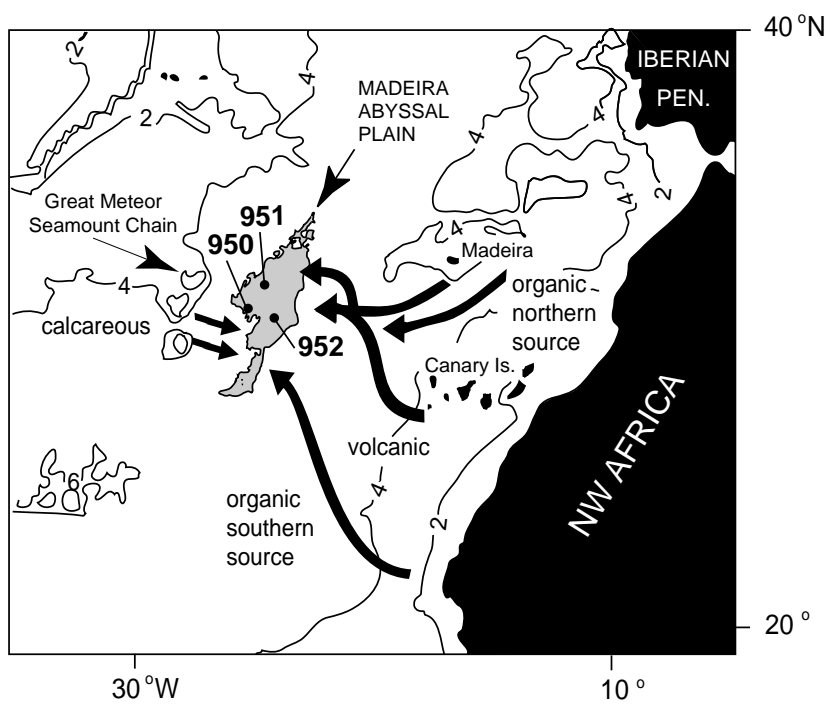

Figure 1. Location map for the Madeira Abyssal Plain showing the inferred source directions of the main turbidite groups that form most of the Neogene-Quaternary turbidite sequence. The locations of Sites 950, 951, and 952 are also shown.

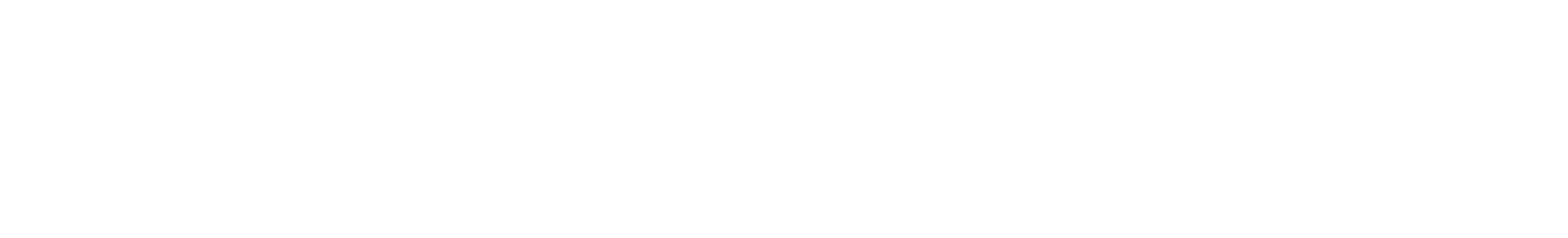


Madeira; the Northwest African continental slope; and seamounts and hills to the west of the plain). These turbidites are separated by bioturbated oozes, marls, and clays representing pelagic intervals (Weaver and Rothwell, 1987). Over the last 300,000 yr, $600 \mathrm{~km}^{3}$ of turbidites, compared with $60 \mathrm{~km}^{3}$ of pelagic sediments, have been deposited on the plain (Rothwell et al., 1992). The pattern of turbidite deposition is of considerable interest, as many turbidites are of particularly large volume (as much as $200 \mathrm{~km}^{3}$ for individual flows) and seem to have been emplaced at times of sea-level change (Weaver and Kuijpers, 1983), rather than at times of low sea-level stands, as on many fan systems.

During Ocean Drilling Program (ODP) Leg 157, three sites (950952) were drilled on the Madeira Abyssal Plain (Figs. 1, 2) with the aim of dating the inception of the abyssal plain, determining the frequency of turbidite deposition, and calculating mass balances for sedimentary erosion and redeposition within the Canary Basin. Site 950 was drilled close to the western margin of the abyssal plain at the mouth of the Cruiser Fracture Zone Valley. Here, the entire turbidite sequence was penetrated, recovering $381 \mathrm{~m}$ of sediment with $90 \%$ core recovery, which was virtually continuous down to 100 meters below seafloor (mbsf). Site 951 was drilled $109 \mathrm{~km}$ north of Site 950 in the Charis Fracture Zone Valley, near the northwestern margin of the abyssal plain (Fig. 2). A total of $351.6 \mathrm{~m}$ of sediment was recovered at this site, but the base of the turbidite sequence was not reached. Recovery was excellent, with $98 \%$ recovery in Hole 951A (0-256.6 mbsf) and 88\% in Hole 951B (256-351.6 mbsf). Site 952 was a more proximal site than either Sites 950 or 951 and was drilled $128 \mathrm{~km}$ south-southeast of Site 951 and $121 \mathrm{~km}$ east-southeast of Site 950, in the eastward trace of the Cruiser Fracture Zone Valley, near the eastern edge of the abyssal plain (Fig. 2). Sediments recovered at Site 952 comprised $425 \mathrm{~m}$ of turbidite muds, silts, and sands and interbedded pelagic muds. As at Site 951, the base of the turbidite sequence was not reached, although recovery was excellent at $97 \%$.
The data collected during the drilling leg are presented by Schmincke, Weaver, Firth, et al. (1995).

Since 1980, a large number of single-channel seismic lines $(\sim 8000 \mathrm{~km})$ have been made across the Madeira Abyssal Plain, principally by the Rijks Geologische Dienst (RGD; State Geological Survey) of the Netherlands and the Institute of Oceanographic Sciences (U.K.). These data have been analyzed by Duin and Kok (1984) and Searle (1987). The seismic profiles show a relatively simple seismic stratigraphy in which an irregular diffractive acoustic basement is overlain by three distinctive seismic units that appear to reflect a great thickness of ponded turbidites overlying pelagic drape. Seismic profiles across the plain show a number of distinct, continuous, and laterally extensive reflectors within the turbidite sequence. Several authors have speculated on their origin and age (Duin and Kuijpers, 1983; Duin and Kok, 1984; Searle, 1987). Through deep drilling on Leg 157 , we can now identify with a reasonable degree of certainty the lithologies that give rise to these reflectors. The seismic reflectors are well developed at each drill site, and the turbidite sequence has approximately the same thickness. In this paper, we identify the ages and lithologies of these prominent seismic reflectors through integration of the large seismic reflection profile data set with lithologic and wireline log data. We also map the extent and probable volume of the distinct packages of allochthonous sedimentation that make up the turbidite sequence.

\section{PREVIOUS RESEARCH}

Although the existence of abyssal plains were first reported by Tolstoy and Ewing (1949) following the 1947 Mid-Atlantic Ridge Expedition and their probable origin (through the progressive burial of ridge flank topography by deposits from turbidity currents) had been explained as early as 1951 by Heezen et al. (1951), abys-

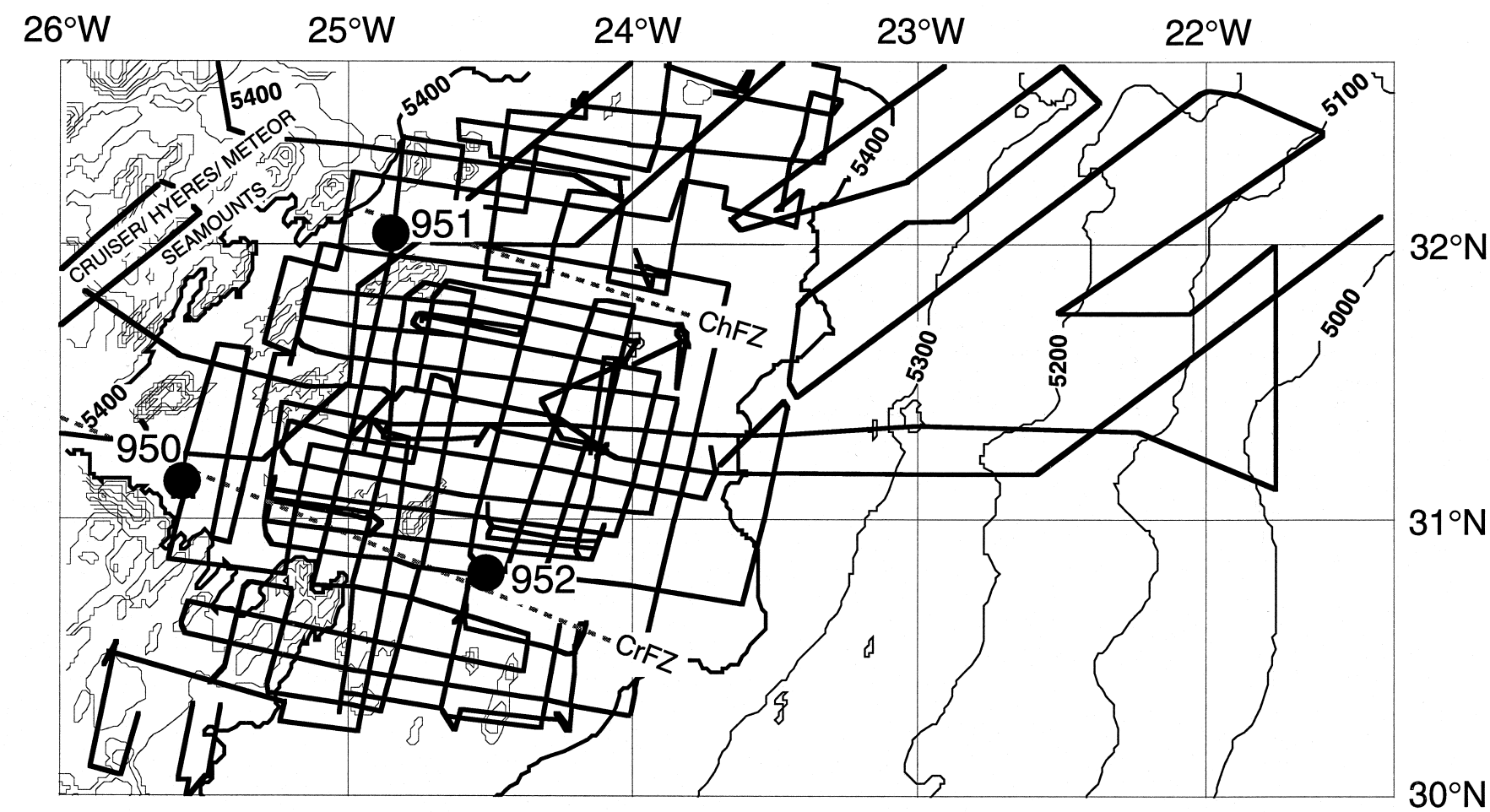

Figure 2. Map showing the locations of seismic reflection profile lines used in the present study to construct total depth to seismic reflectors and isopach maps of the seismic units. The locations of Leg 157 sites are also shown. Contour interval is $100 \mathrm{~m}$. The two fracture zone traces that cross the abyssal plain are shown by dashed lines $(\mathrm{ChFZ}=$ Charis Fracture Zone and $\mathrm{CrFZ}=$ Cruiser Fracture Zone $)$. 
sal plains formed a relatively unknown deep-sea sedimentary province until relatively recently. Knowledge of abyssal plain sediments was previously limited, as abyssal plain sediments tend to be subducted in the long term and thus are generally rare in the geologic record.

The development of a high-resolution stratigraphy (Weaver and Kuijpers, 1983; Kidd et al., 1983) provided a detailed picture of how the Madeira Abyssal Plain was built up, layer by layer, for the most recent Quaternary (i.e., within the limits of conventional piston coring). During the $1980 \mathrm{~s}$, a total of $8 \times 10^{3} \mathrm{~km}$ of single-channel seismic reflection profiles, $28 \times 10^{3} \mathrm{~km}$ of high-frequency seismic profiles (3.5-12 kHz.), $70 \times 10^{3} \mathrm{~km}^{2}$ of Geological Long Range Inclined Asdic (GLORIA) sidescan sonar coverage, and 160 sediment cores (of which 88 are piston cores) were collected by a series of cruises run by the Institute of Oceanographic Sciences (U.K.) and the RGD. In 1985, an international cruise-the "Etude des Sediments Oceaniques par Penetration" expedition organized by the NEA - obtained five long piston cores (up to $34 \mathrm{~m}$ in length) from the central part of the plain (Schuttenhelm et al., 1989). Major papers published on the geological history of the plain, based on the analysis of piston cores, are Weaver and Kuijpers (1983), Weaver and Rothwell (1987), Weaver et al. (1992), and Rothwell et al. (1992). These showed that late Quaternary sedimentation on the abyssal plain has been dominated by large-volume turbidite muds, some of which can be correlated across the entire plain. These turbidite muds are derived from at least four main sources: the continental slope to the southeast of the plain; the continental slope to the northeast of the plain; the flanks of the volcanic islands of the Canaries and, possibly, Madeira; and the flanks of seamounts to the west of the plain. These different sources result in different types of turbidite- organic rich (derived from the continental slope), volcanic rich (derived from the flanks of volcanic islands), and calcareous (derived from the flanks of seamounts) - and many turbidites appear to have been emplaced at times of climatic/sea-level change.

Duin and Kok (1984) and Searle (1987) specifically discuss the seismic stratigraphy of the abyssal plain on the basis of $6750 \mathrm{~km}$ of seismic reflection profiles collected by the HNMS Tydeman in 1980, the MS Tyro in 1982, and $\sim 1500 \mathrm{~km}$ of air gun seismic reflection profiles collected by several cruises run by the Institute of Oceanographic Sciences (U.K.). Duin and Kok (1984) recognized a fourfold division of the seismic stratigraphy: an upper stratified Unit A (interpreted as ponded turbidites) underlain by an acoustically transparent Unit $\mathrm{B}$ (interpreted as pelagic sediments with interbedded turbidites); a lower stratified Unit C (interpreted as turbidites or possibly volcaniclastic deposits); and a basal transparent sediment Unit D. These units were separated by prominent laterally continuous reflectors of regional importance, which could generally be traced across the entire abyssal plain, although they become less distinct toward the continental rise in the east. The most significant of these are Reflector 2 (r2), a prominent continuous reflector showing high amplitude over the entire abyssal plain and dividing Unit A from Unit B, and Reflector 4 (r4), a generally strong, very continuous reflector that marks the base of Unit B (the base of the stratified turbidite sequence).

Searle (1987) recognized a twofold division of the seismic stratigraphy, grouping Duin and Kok's (1984) Units A, B, C, and D into single Units $A B$ and $C / D$, believing Unit $D$ to represent a facies change within the lower sequence and $\mathrm{A}$ and $\mathrm{B}$ to represent a single lithologic unit. Based on the simple two-stage sedimentation model of Weaver et al. (1986), Searle predicted that most of the lowermost sedimentary unit (C/D) would be pelagic clay because the area would have lain below the calcium carbonate compensation depth (CCD) for most of its history (Weaver et al., 1986).

Both Duin and Kok (1984) and Searle (1987) present total sediment thickness and total depth to basement maps for the abyssal plain, and Duin and Kok (1984) also present isopach maps for their Turbidite Unit A and for the combined thickness of Units A and B.

\section{SEISMIC STRATIGRAPHY}

The Madeira Abyssal Plain shows a relatively simple seismic stratigraphy with, at its most basic level, a twofold subdivision: an upper horizontally to subhorizontally stratified unit containing many strong, parallel, continuous reflectors (Units A and B of Duin and Kok, 1984; Unit AB of Searle, 1987) and a lower variably stratified, but commonly almost transparent, unit (Units C and D of Duin and Kok, 1984; Unit C/D of Searle, 1987) overlying irregular, diffractive oceanic basement. Total sediment thickness across the abyssal plain varies from 0 to $>2000 \mathrm{~m}$, although sediment thickness is $>250 \mathrm{~m}$ under most of the plain. Sediment thickness closely correlates with the shape of the underlying oceanic basement. The greatest sediment thicknesses occur in basement lows under the plain and in the fracture zone valleys (Searle, 1987). The sediments overlie basaltic oceanic basement formed at the Mid-Atlantic Spreading Center in the Late Cretaceous (80-106 Ma; Searle, 1987).

Analysis of single-channel water gun seismic reflection profiles collected across the drill sites during Leg 157 resulted in a threefold division of the sediment fill, based on the acoustic character of the records (Schmincke, Weaver, Firth, et al., 1995). The upper Unit A, characterized by abundant subhorizontal to horizontal continuous reflectors of relatively high amplitude, corresponds to Units A and B of Duin and Kok (1984) and Unit AB of Searle (1987). Units B (characterized by a few high amplitude reflectors) and $\mathrm{C}$ (mainly acoustically transparent but containing a few reflectors of low coherency that are largely confined to the upper part of the unit) correspond to the Units C and D of Duin and Kok (1984) and C/D of Searle (1987).

Unit A was further subdivided into three subunits: A1, A2, and A3 (Schmincke, Weaver, Firth, et al., 1995), which identify discrete sediment packages within the Neogene turbidite sequence. Seismic reflectors in A1, the uppermost subdivision, are parallel and continuous and are relatively strong compared with those in the underlying subunits (A2-A3). A2 also is generally well stratified. A3 is generally poorly stratified and almost acoustically transparent, although it does contain reflectors toward the sides of the basin. Subunits A1 through A3 are all separated by strong, well-defined reflectors that are continuous over most of the abyssal plain. The thickness of the series A1A3 ranges from 150 to $560 \mathrm{~ms}$; therefore, the upper series may be more than $400 \mathrm{~m}$ thick in places (Searle, 1987).

Post-cruise analysis of the large existing set of seismic reflection profiles, together with the short profiles collected across the drill sites during Leg 157, have allowed us to further subdivide seismic Subunit A1 into two units, which we term A0 (the uppermost unit) and A1, separated by Reflector $\mathrm{r} 0$, a moderately strong, generally high-amplitude, continuous reflector that can be traced across the abyssal plain and lies at 50-80 ms sub-bottom depth. Seismic Unit A0 is the uppermost seismic unit in the sequence and is a horizontally to subhorizontally stratified unit; the reflectors are strong, parallel, generally continuous, and of relatively high amplitude (10-25 ms). Seismic Unit A1 is $50-100 \mathrm{~ms}$ in thickness and also shows strong, high-amplitude reflectors. There is a downward increase in reflector amplitude from A0 to A1. Seismic Unit A2 ranges between 50 and $110 \mathrm{~ms}$ in thickness and has an upper transparent part and a more stratified lower part in which reflectors are more widely spaced than in the overlying units. Unit A3 has a thickness between 50 and $300 \mathrm{~ms}$. Although it does contain some strong continuous reflectors near its upper boundary, it usually appears as acoustically transparent. On some seismic lines, A3 is not transparent, and this acoustic character may reflect the presence of locally developed reflectors. Reflectors within seismic Units A0 to A3 show clear onlap onto basement highs. The division into seismic Units A0 to A3 is far less clear at Site 951 than at Sites 950 and 952. At Site 951, the lower part of A3 contains several strong, but locally developed, subparallel reflectors, and the typical acoustic transparent nature of this unit is less marked. However, the character of seismic Units A0 to A3 is generally consistent across 
most of the abyssal plain. The thickness of the upper seismic series A0-A3, and the subunits within it, are relatively constant at all three drill sites; it is $390 \mathrm{~ms}$ thick at Site 950, $400 \mathrm{~ms}$ thick at Site 951, and $445 \mathrm{~ms}$ at Site 952 (Schmincke, Weaver, Firth, et al., 1995).

Units A0 through A3 overlie Unit B with a clear unconformity, the surface of which forms the prominent regional Reflector 4 (r4), described by Duin and Kok (1984) and Searle (1987). Unit B is a variably stratified unit containing parallel reflectors that onlap onto basement highs and drape the relief of the acoustic basement. Some of the reflectors of this unit are parallel and continuous, whereas others laterally lose their continuity. Chaotic patterns are seen within the unit in some profiles, especially over basement highs; therefore, the internal reflector pattern may be complex. We consider the underlying Unit C, described by Schmincke, Weaver, Firth, et al. (1995), probably represents facies changes near the base of the pelagic sequence; consequently, we recognize only a single unit (B) below seismic Units A0 through A3.

The acoustic character of the seismic units, together with age and lithologic correlation derived from the drill site data (see discussion below), are presented in Table 1. A representative profile across the abyssal plain showing the character of the seismic units is illustrated in Figure 3.

\section{CORRELATION OF LITHOLOGY AND SEISMIC UNITS AT SITES 950, 951, AND 952}

Drilling at Sites 950 through 952 has allowed the nature of the seismic units to be identified and the ages they represent to be determined. An excellent sonic log was obtained in Hole 950A, and a complete velocity profile was obtained down to $340 \mathrm{mbsf}$ by combining the log data with the multisensor track (MST) velocities measured on the recovered cores (Schmincke, Weaver, Firth, et al., 1995). A twoway traveltime (twt) depth relationship derived from this log and published in Schmincke, Weaver, Firth, et al. (1995) allows precise correlation between the seismic profiles and the downcore lithologic $\log$ from each drill site (Table 2; Figs. 4-6).

The turbidites of the Madeira Abyssal Plain are visually striking, and many are several meters thick. The turbidites are highly distal and, over most of the plain, consist of thick, structureless, ungraded muds. They consequently fall into the $\mathrm{E}_{3}$ division in Piper's scheme (Piper, 1978) and $\mathrm{T}_{7}-\mathrm{T}_{8}$ of Stow and Shanmugam (1980). However, proximally, in the east of the plain, the lowermost few centimeters are commonly weakly laminated or graded (Piper's $\mathrm{E}_{1}$ and $\mathrm{E}_{2}$ divisions; Stow and Shanmugam's $T_{3}-T_{6}$ ), or develop coarser graded bases (Weaver and Rothwell, 1987; Rothwell et al., 1992). With respect to lithology, the turbidites are composed predominantly of coccolith plates and clay-grade detrital material and, using the classification of Mazzullo et al. (1988), are characterized as nannofossil oozes, clayey nannofossil oozes, clayey nannofossil mixed sediments, and nannofossil clays.

We distinguish four basic classes of turbidites: organic-rich turbidites (containing $>0.3 \%$ organic carbon; derived from the Northwest African Margin), volcanic-rich turbidites (with high $\mathrm{TiO}_{2}$ contents and low organic carbon; derived from the Canaries and, possibly, Madeira), calcareous turbidites with over $75 \% \mathrm{CaCO}_{3}$ derived from seamounts to the west of the plain (De Lange et al., 1987; Middelburg and De Lange, 1988), and a type which we term "intermediate." These intermediate turbidites are gray or brown colored turbidites of variable thickness. Although they commonly closely resemble the volcanic-rich turbidites in visual appearance, calcium carbonate, and organic carbon content, their low magnetic susceptibility suggests the absence of a volcanic component (Lebreiro et al., Chap. 30, this volume). All turbidite classes may either show or lack coarser grained sandy or silty bases. In the turbidites derived from the Northwest African Continental Margin, sandy bases are commonly domi- nated by quartz and planktonic and benthic foraminifers (Weaver and Rothwell, 1987; Lebreiro et. al., Chap. 30, this volume). Basal silts and sands of volcanic-rich turbidites contain anhedral feldspar, volcanically derived accessory minerals, and volcanic glass (Weaver and Rothwell, 1987; Lebreiro et. al., Chap. 30, this volume), whereas calcareous turbidites are commonly underlain by foraminifer sands.

Genetic logs for the turbidite sequence at each drill site are published by Schmincke, Weaver, Firth, et al. (1995) and are shown in Figures 4 through 6 as downhole genetic logs, together with equivalent lithologic subunits, seismic units, and ages (from Howe and Sblendorio-Levy, Chap. 29, this volume) with the corresponding JOIDES Resolution seismic reflection profile across the drill site. At all drill sites, seismic Unit A0 represents the Pleistocene sequence, A1 is the late Pliocene sequence, A2 is late Miocene to early Pliocene, and A3 is middle to late Miocene in age.

The proportions of the different turbidite types clearly vary between the different seismic units (Fig. 7). Although organic-rich turbidites are clearly the dominant turbidite class in all of the units, commonly constituting $60 \%-80 \%$ of the total turbidite thickness in each unit, the proportion of the units they make up shows an overall increase downhole through Units A0 to A3. The proportion of organicrich turbidites increases by $15 \%$ from Units A0 to A1 at all three drill sites, but decreases by $5 \%-10 \%$ from A1 to A2. The proportion of organic-rich turbidites in seismic Units A2 and A3 at Sites 950 and 952 is similar, but at Site 951, the proportion of organic-rich turbidites in A 3 rises by $15 \%$. The proportion of volcanic turbidites within the seismic units decreases quite markedly from A0 to A3, with the greatest proportion of volcanic-rich turbidites in Unit A0 $(25 \%-30 \%$ of the total turbidite thickness within this unit, depending on the drill site). In seismic Unit A1, volcanic-rich turbidites make up 10-20\% of the total turbidite thickness, compared with only 5\%-10\% in Units $\mathrm{A} 2$ and $\mathrm{A} 3$.

Downhole plots of turbidite thickness (not corrected for compaction) for each turbidite type and basal turbidite sand layers for each drill site are presented in Figures 8 through 10 . The depth to the boundaries of each seismic unit at each drill site is shown in Table 2. Seismic Unit A0 represents the Pleistocene sequence, and this unit is distinctive in that it is the most distinctly horizontally stratified unit. It contains numerous strong, parallel, continuous reflectors of relatively high amplitude. Lithologically, the unit is made up of thick to very thick turbidites, commonly separated by thin pelagic intervals, with organic-rich turbidites as the dominant type. However, volcanic-rich turbidites are more numerous and generally thicker than in the underlying seismic units. Calcareous turbidites are typically thin in Unit A0, and "intermediate" turbidites are rather rare.

Seismic Unit A1 (late Pliocene in age) equates to a sequence of very thick to thin bedded turbidites interlayered with thin pelagic intervals. This unit shows a decrease in frequency and thickness of volcanic-rich turbidites, although there is some variability among the three drill sites (Figs. 8-10). Organic-rich turbidites in A1 are generally thicker than the volcanic-rich turbidites and form the dominant turbidite type.

Seismic Unit A2 is late Miocene to early Pliocene in age. This unit comprises a sequence of medium to very thick bedded volcanic-rich and organic-rich turbidites, interlayered with thin pelagic intervals. Organic-rich turbidites are the dominant type, and volcanic-rich turbidites are rare in the lower part of A2, which is acoustically transparent on seismic reflection profiles.

Seismic Unit A3, which is the lowest unit in the turbidite sequence at Site 950 (but not at Sites 951 and 952), is late to middle Miocene in age. On seismic records, this unit is poorly stratified and almost acoustically transparent. It comprises a great thickness $(\sim 60-150 \mathrm{~m})$ of thin organic-rich turbidites and almost no volcanic turbidites (Figs. $8-10)$. Near the top of the unit, a number of volcanic-rich turbidites of moderate thickness occur, and these appear to correlate broadly with a number of strong continuous, parallel reflectors seen near the 
Table 1. Character of seismic units, reflector notation and position, acoustic character with corresponding age, and lithology from Sites 950, 951, and 952.

\begin{tabular}{|c|c|c|c|c|c|c|}
\hline \multicolumn{3}{|c|}{ SEISMIC UNITS } & \multirow{2}{*}{ REFLECTOR } & \multirow{2}{*}{ AGE $^{\star}$} & \multirow{2}{*}{ ACOUSTIC CHARACTER } & \multirow{2}{*}{ LITHOLOGY } \\
\hline Duin and Kok, 1984 & Searle, 1987 & This paper & & & & \\
\hline \multirow{3}{*}{ A } & \multirow{4}{*}{$A B$} & A0 & & Pleistocene & $\begin{array}{l}\text { Horizontally to subhorizontally stratified unit; reflectors are } \\
\text { strong, parallel, generally continuous, and of relatively high } \\
\text { amplitude (10-25 ms). }\end{array}$ & $\begin{array}{l}\text { Generally thick to very thick turbidites separated by thin } \\
\text { pelagic intervals. Organic-rich turbidites are the dominant } \\
\text { type. Volcanic-rich turbidites are more numerous and } \\
\text { generally thicker than in the underlying unit } \mathrm{A} 1 \text {. }\end{array}$ \\
\hline & & A1 & & $\begin{array}{l}\text { late } \\
\text { Pliocene }\end{array}$ & $\begin{array}{l}\text { Generally well-stratified, especially in the lower part, which } \\
\text { shows strong, high amplitude reflectors. There is a downward } \\
\text { increase in reflector amplitude ( } 15-30 \mathrm{~ms}) \text { from A0 to A1. }\end{array}$ & $\begin{array}{l}\text { Very thick to thin bedded turbidites interlayered with thin } \\
\text { pelagic intervals. Organic-rich turbidites are generally } \\
\text { thicker than volcanic-rich turbidites and form the dominant } \\
\text { turbidite type. }\end{array}$ \\
\hline & & A2 & & $\begin{array}{l}\text { early } \\
\text { Pliocene } \\
\text { - late } \\
\text { Miocene }\end{array}$ & $\begin{array}{l}\text { Generally transparent, but with a few strong reflectors near } \\
\text { the base and top of the unit }\end{array}$ & $\begin{array}{l}\text { Medium to very thick-bedded volcanic-rich and organic- } \\
\text { rich turbidites interlayered with thin pelagic sediments. } \\
\text { Organic-rich turbidites are generally the dominant type. }\end{array}$ \\
\hline $\mathrm{B}$ & & A3 & & $\begin{array}{l}\text { late - } \\
\text { middle } \\
\text { Miocene }\end{array}$ & $\begin{array}{l}\text { Poorly stratified and almost transparent unit, but reflectors } \\
\text { appear toward the sides of the basin. }\end{array}$ & $\begin{array}{l}\text { Turbidites with thin pelagic intervals. Organic-rich } \\
\text { turbidites are the dominant type and are generally thinner } \\
\text { than in the overlying units. Volcanic-rich turbidites are rare } \\
\text { and typically thin in the lower part of A3. The base is } \\
\text { marked by distinctive calcarenite bed. }\end{array}$ \\
\hline C & \multirow[t]{2}{*}{$\mathrm{C} / \mathrm{D}$} & \multirow[t]{2}{*}{ B } & & $\begin{array}{l}\text { middle } \\
\text { Miocene - } \\
\text { ? Coniacian }\end{array}$ & $\begin{array}{l}\text { Variably stratified unit. Parallel reflectors onlap onto basement } \\
\text { highs and drape the relief of the acoustic basement. Some } \\
\text { reflectors are parallel and others lose their continuity. Chaotic } \\
\text { patterns occur especially over the basement highs. }\end{array}$ & $\begin{array}{l}\text { Red pelagic clays containing thin interbeds of clayey } \\
\text { nannofossil mixed sediment and zeolitized volcanic ash } \\
\text { bands in the upper part of the unit. Lower part not drilled. }\end{array}$ \\
\hline D & & & & & containing few reflectors which show low coherency. & \\
\hline $\mathrm{Ac}$ & & & & & & \\
\hline
\end{tabular}

Note: Ages from Howe and Sblendorio-Levy (Chap. 29, this volume), correlated with seismic units on cross-site seismic profiles. 

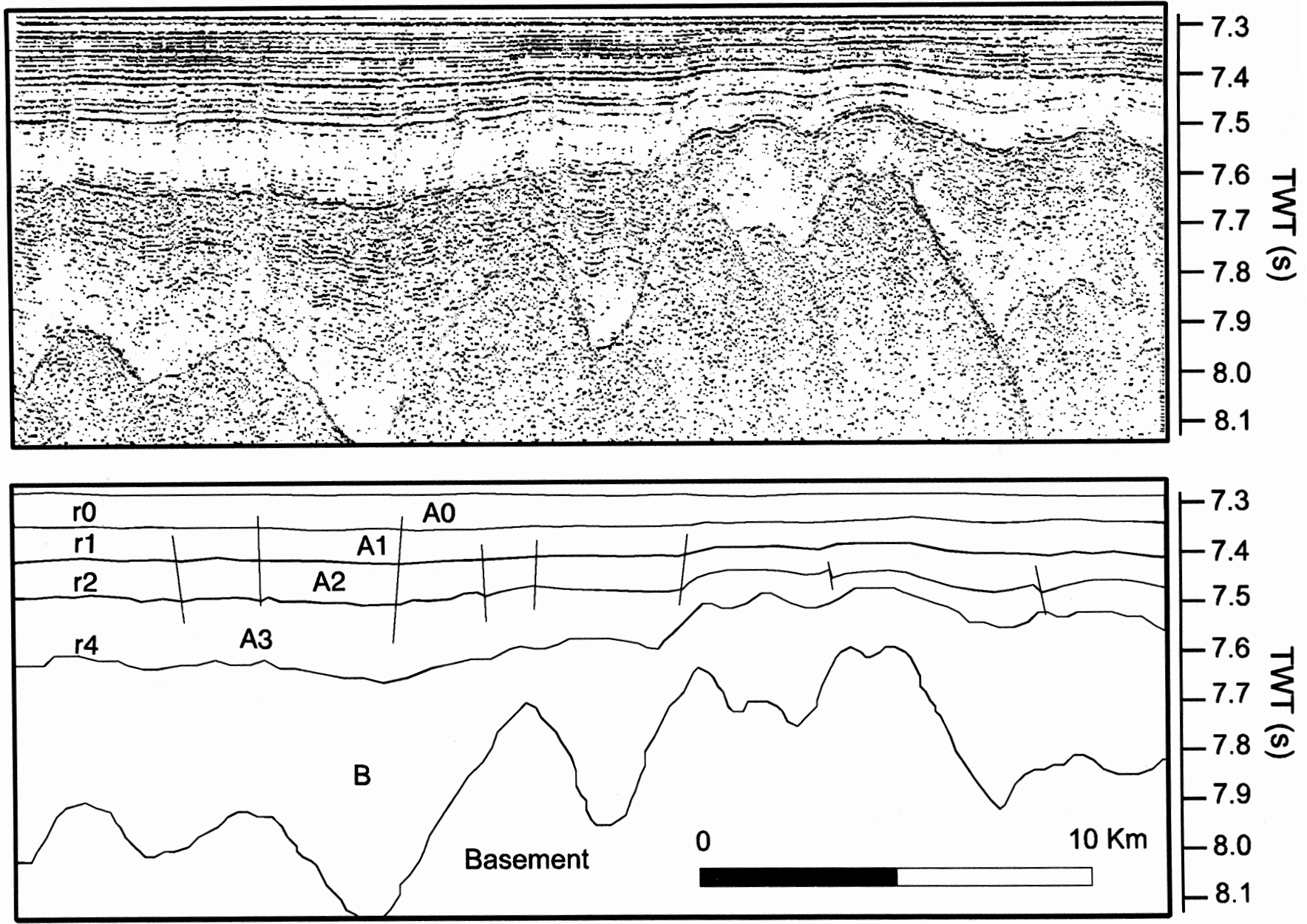

Figure 3. Sample seismic reflection profile across the abyssal plain with interpretation below showing the clearly defined seismic units, bounded by strong, laterally continuous reflectors. Depth scale is depth in seconds below the sea surface.

top of Unit A3 on seismic profiles. However, most of the unit is acoustically transparent, and this seems to equate with the thick series of thinly bedded, organic-rich turbidite muds. A number of calcareous turbidites are found in this interval at Site 950, but they are less frequent at Sites 951 and 952. Weaver and Rothwell (1987) and Rothwell et al. (1992) showed that in the late Quaternary, calcareous turbidites (e.g., turbidite j), derived through instability on seamounts to the west of the plain, entered the abyssal plain through the Cruiser Fracture Zone Valley. The greater occurrence of calcareous turbidites in A3 at Site 950 testifies to the long-standing role of the Cruiser Fracture Zone Valley as a conduit for allochthonous calcareous sediment during the Neogene.

In an attempt to tie in geologic horizons recovered at Site 950 to seismic data, a synthetic seismogram was calculated (Fig. 11). However, instead of using the seismic line collected across Site 950 by the JOIDES Resolution, we have used a seismic line collected by the $M S$ Tyro in 1982 that crosses the drill site, because it shows higher resolution. The impedance log was calculated from the density and the sonic logs. The impedance log was then convolved with the source wavelet to calculate the synthetic seismogram (Fig. 11). Velocity data (from MST measurements and the sonic log) and density data (gamma-ray attenuation porosity evaluator densities, measured with the MST, and bulk densities, measured with the high lithodensity tool), were used to produce the impedance log for Site 950. The impedance log was convolved with the MS Tyro 1982 cruise source (80- in $^{3}$ water gun) wavelet, derived from 500 traces from the data set as recorded and bandpass filtered $(50-180 \mathrm{~Hz}$; C. Mesdag, pers. comm., 1996), to calculate a synthetic seismogram. The synthetic seismogram produced ties quite well with the MS Tyro 1982 cruise seismic line, which crosses the Site 950 drill site (Fig. 11), showing higher peaks in the upper part where reflectors are stronger, and the smaller peaks where the seismic character is more acoustically transparent. The synthetic seismogram shows Reflector 4 as a high peak, which coincides with the calcarenite recovered at the equivalent depth. We have not calculated a synthetic seismogram for Site 951, as this site was not logged, nor for Site 952, as this site was logged only to 269 mbsf because of an obstruction, despite the hole reaching $425.9 \mathrm{mbsf}$.

\section{METHODS USED TO PRODUCE ISOPACH AND TOTAL DEPTH MAPS AND ASSOCIATED PROCESSING}

We are now able conclusively to date and determine the character of the seismic units identified on seismic reflection profiles across the Madeira Abyssal Plain through deep drilling at Sites 950, 951, and 952. We can identify discrete packages of plain sediments of different age and overall character. Units can be mapped laterally using the already existing, extensive data set of seismic reflection profiles. The extent and probable volume of the distinct packages of allochthonous 
Table 2. Depths to reflectors and bases of seismic units at Sites 950, 951, and 952.

\begin{tabular}{|c|c|c|c|c|c|c|c|c|}
\hline \multicolumn{2}{|c|}{$\begin{array}{c}\text { Seismic } \\
\text { Unit }\end{array}$} & \multirow{2}{*}{ 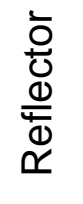 } & \multicolumn{2}{|c|}{ Site 950} & \multicolumn{2}{|c|}{ Site 951} & \multicolumn{2}{|c|}{ Site 952} \\
\hline & & & $\begin{array}{l}\text { twt } \\
\text { (ms) }\end{array}$ & $\begin{array}{l}\text { Depth } \\
\text { (mbsf) }\end{array}$ & $\begin{array}{l}\text { twt } \\
\text { (ms) }\end{array}$ & $\begin{array}{l}\text { Depth } \\
\text { (mbsf) }\end{array}$ & $\begin{array}{l}\text { twt } \\
\text { (ms) }\end{array}$ & $\begin{array}{l}\text { Depth } \\
\text { (mbsf) }\end{array}$ \\
\hline \multirow{5}{*}{ A } & A0 & \multirow{2}{*}{ r0 } & \multirow{2}{*}{8} & \multirow{2}{*}{70} & \multirow{2}{*}{85} & \multirow{2}{*}{68} & \multirow{2}{*}{85} & \multirow{2}{*}{64} \\
\hline & A1 & & & & & & & \\
\hline & & \multirow{2}{*}{ r2 } & -180 & 140 & 180 & 140 & 160 & 120 \\
\hline & & & \multirow{2}{*}{-240} & \multirow[t]{2}{*}{200} & \multirow[t]{2}{*}{235} & \multirow[t]{2}{*}{190} & \multirow[t]{2}{*}{245} & \multirow[t]{2}{*}{190} \\
\hline & A3 & & & & & & & \\
\hline & & $-r 4$ & -390 & \multirow[t]{2}{*}{330} & \multirow[t]{2}{*}{400} & \multirow[t]{2}{*}{320} & \multirow[t]{2}{*}{445} & \multirow[t]{2}{*}{370} \\
\hline & & & & & & & & \\
\hline
\end{tabular}

Note: Two-way traveltime (twt) in milliseconds and depth below seafloor in meters (mbsf) for r1 to r4 from Schmincke, Weaver, Firth, et. al. (1995).

sedimentation that make up the turbidite sequence can now be described and calculated.

Mapping the extent of the individual seismic units and the reflectors that bound them began with digitizing the seafloor; Reflectors 0 , 1,2 , and 4 ; and the top of the basement on seismic reflection profiles. This produced a file in which the data are distributed along lines that needed to be redistributed as a regular grid (i.e., a Digital Terrain Model [DTM]). We calculated these DTMs using the Kriging method, considered the most suitable for this distribution of the data. Travel times were converted into depth using a smoothed velocity-depth function for each site, derived from the sonic log.

Assuming that velocity increases linearly with depth,

$$
v=v 0+c z,
$$

where $v O$ is the velocity at $0 \mathrm{mbsf}, \mathrm{c}$ is the velocity increase, and $z$ is the depth. The best fit was with functions of the type $T W T=(2000 /$ c) $\ln (1+c z / v 0)$, namely: $T W T=2.13 \ln (1+0.00059 z) ; v=1584+$ $0.937 z$ for Site 950 and $T W T=2.10 \ln (1+0.00065 z) ; v=1460+$ $0.953 z$ for Site 952 (Lykke-Andersen, pers. comm., 1996). The average, $T W T=2.115 \ln (1+0.00062 z)$, was used as the regional velocity function for the Madeira Abyssal Plain to convert the time DTM to depth.

The DTMs were contoured using the computer program Surfer for Windows by Golden Software Inc., Colorado (U.S.A.), producing depth to r0, r1, r2, and $\mathrm{r} 4$ maps (Figs. 12-15). The A0, A1, A2, and A3 isopach maps (Figs. 16-19) were produced by subtracting the DTMs obtained. The mapping of the units throughout the study area enables estimation of their total volume. However, it must be emphasized that these estimates are restricted to the area covered by the seismic lines, which is not the whole area of the Madeira Abyssal Plain, but $\sim 48,600 \mathrm{~km}^{2}$. The calculated volumes need to be corrected for compaction. In order to restore the initial volume of sediment, it is necessary to decompact each unit to the time of deposition. We have followed the method of Van Hinte (1978), who related the original thickness to the present-day thickness as follows:

$$
T_{0}=\left(1-\phi_{N}\right) T_{N} /\left(1-\phi_{0}\right),
$$

where $\phi_{N}$ and $T_{N}$ are the present-day porosity and thickness, and $\phi_{0}$ is the original porosity at the time of deposition.

The present-day porosities were measured on board from discrete samples of $\sim 10-12 \mathrm{~cm}^{3}$, taken from different lithologic layers using dry volume (Schmincke, Weaver, Firth, et al., 1995). The original porosities were estimated for each sediment type using the porosities measured close to the surface, which are not affected by compaction. These values are $70 \%$ for intermediate turbidites, $68 \%$ for calcareous turbidites, $76 \%$ for organic-rich turbidites, $82 \%$ for volcanic-rich turbidites, and $70 \%$ for pelagic intervals. Decompaction was calculated for each lithologic layer, and the results we obtained indicate that compaction has been consistent $(\sim 40 \%)$ across the studied area. Decompacted depth and present depth are related by the following equations:

$$
\begin{gathered}
y=0.64406 \times(1.167) \text { for Site } 950, \\
y=0.72738 \times(1.1469) \text { for Site } 951, \text { and } \\
y=0.72102 \times(1.1383) \text { for Site } 952 .
\end{gathered}
$$

These equations are derived by plotting the middle point of each lithologic layer at the present and decompacted depths at each site. Plots of compacted against decompacted depths show a relationship between these values that can be expressed as an equation. The equations derived at each site are similar, thereby supporting our assumption that compaction is consistent across the studied area. Therefore, the average value, $y=0.6974 \times{ }^{(1.1507)}$, was used as a standard function for the Madeira Abyssal Plain. This equation was applied to the DTMs to recalculate the depths of reflectors if no compaction had occurred-and hence the volumes between them-and a closer value to the real volumes of material emplaced on the plain at these times. With the calculated volumes, their respective areas and the ages (see 


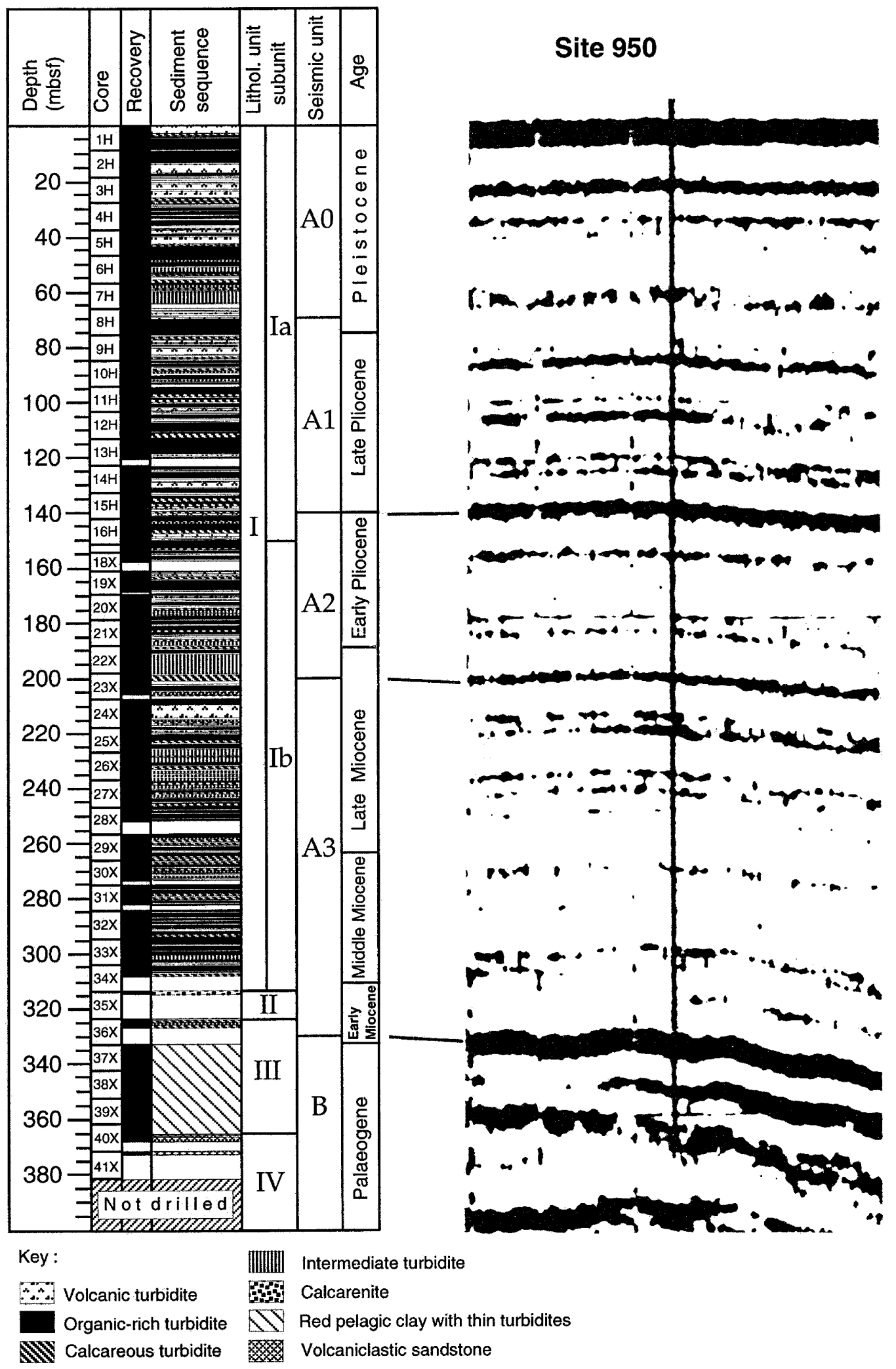

Figure 4. Correlation of the JOIDES Resolution cross-site seismic reflection profile with lithologic column at Site 950. The sediment sequence is shown in terms of a genetic log showing thickness and turbidite type recovered. Boundaries of the shipboard lithologic units and subunits and the boundaries of the seismic units (depth in mbsf, converted from twt) and the corresponding ages of units as determined by Howe and Sblendorio-Levy (Chap. 29, this volume) are also shown. 


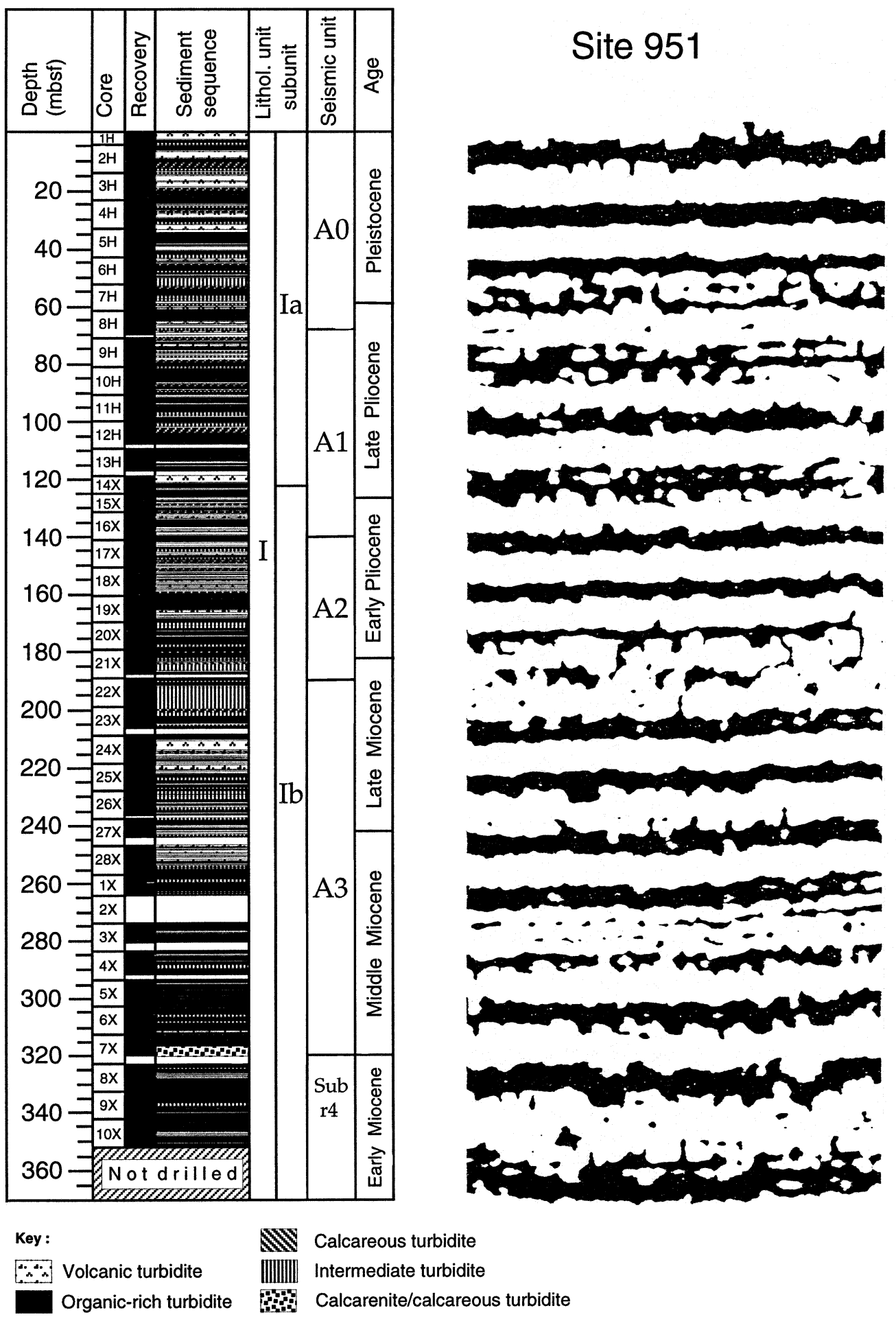

Figure 5. Correlation of the JOIDES Resolution cross-site seismic reflection profile with lithologic column at Site 951. The sediment sequence is shown in terms of a genetic log showing thickness and turbidite type recovered. Boundaries of the shipboard lithologic units and subunits and the boundaries of the seismic units (depth in mbsf, converted from twt) and the corresponding ages of units as determined by Howe and Sblendorio-Levy (Chap. 29, this volume) are also shown. Note the presence of a less well-defined seismic sequence at this drill site, compared with Sites 950 and 952 , caused by the presence of numerous locally developed strong reflectors. 


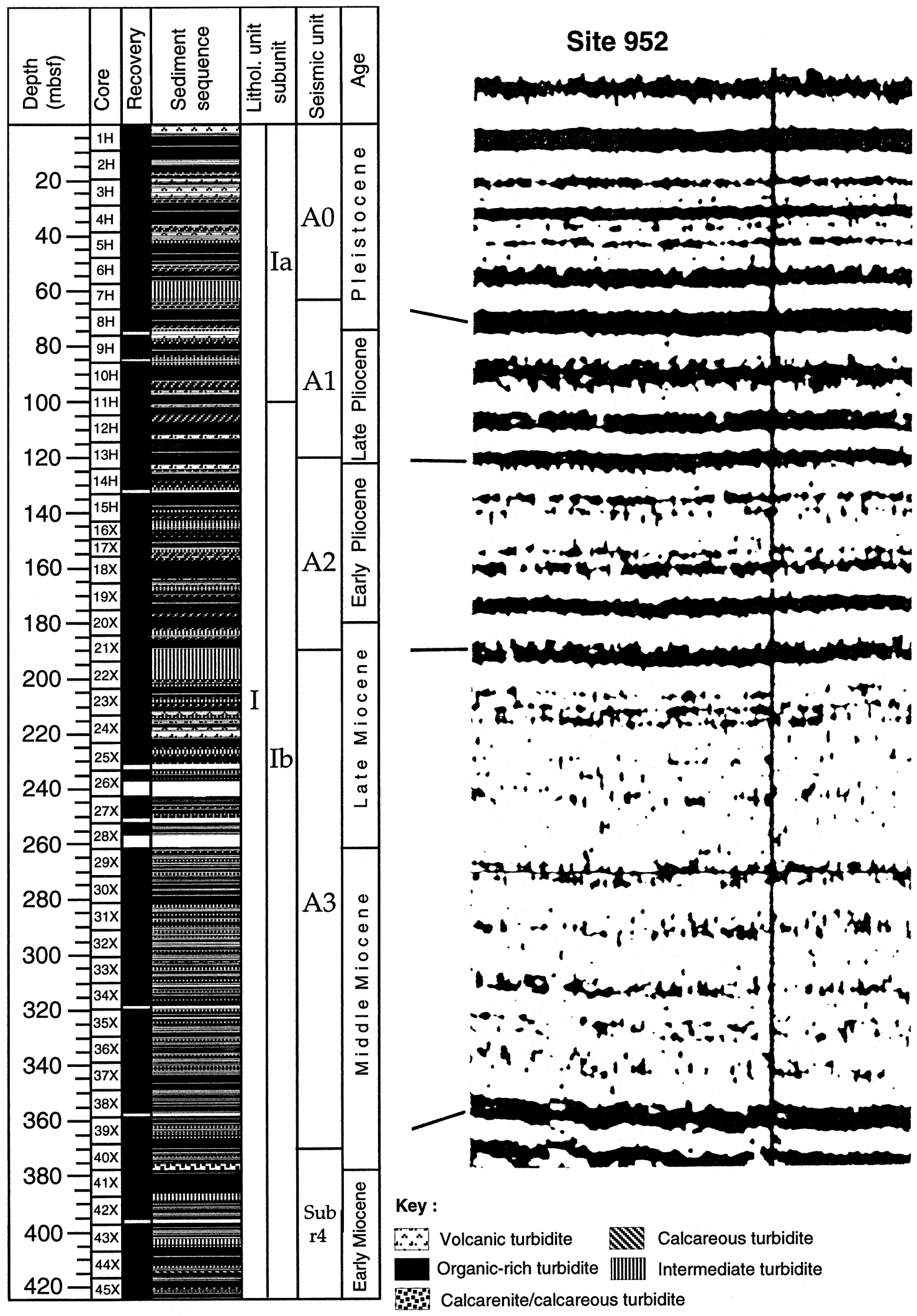

Figure 6. Correlation of the JOIDES Resolution cross-site seismic reflection profile with lithologic column at Site 952. The sediment sequence is shown in terms of a genetic log showing thickness and turbidite type recovered. Boundaries of the shipboard lithologic units and subunits and the boundaries of the seismic units (depth in mbsf, converted from twt) and the corresponding ages of units as determined by Howe and Sblendorio-Levy (Chap. 29, this volume) are also shown. 

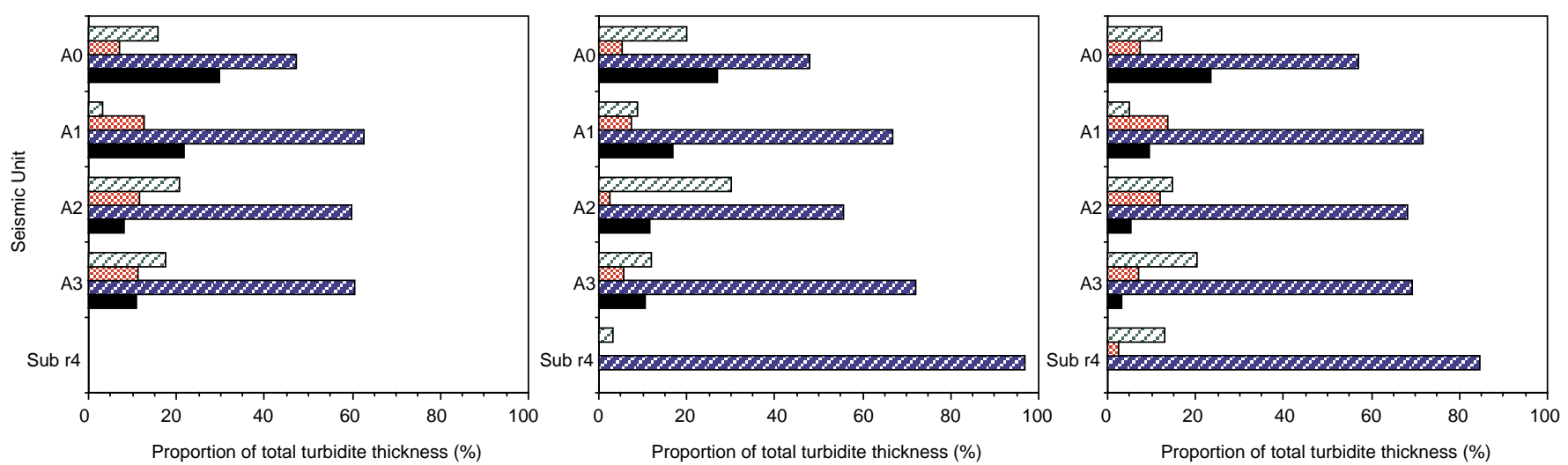

key :

$\mathrm{EZ}$ Intermediate turbidites

Figure 7. Proportions of the different turbidite types within each of the seismic units at each drill site, shown as a percentage of the total turbidite thickness within each seismic unit.

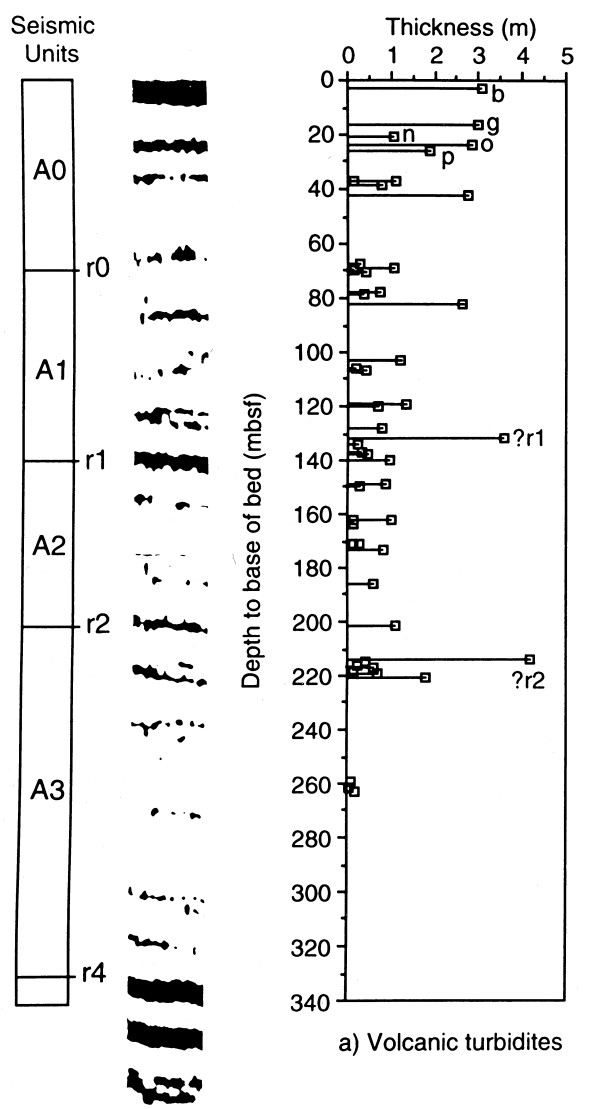

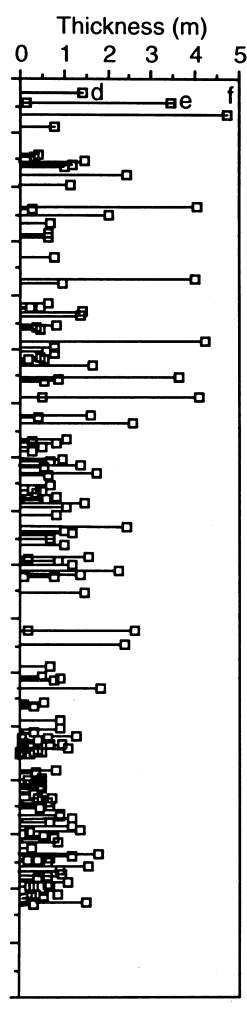

b) Organic turbidites

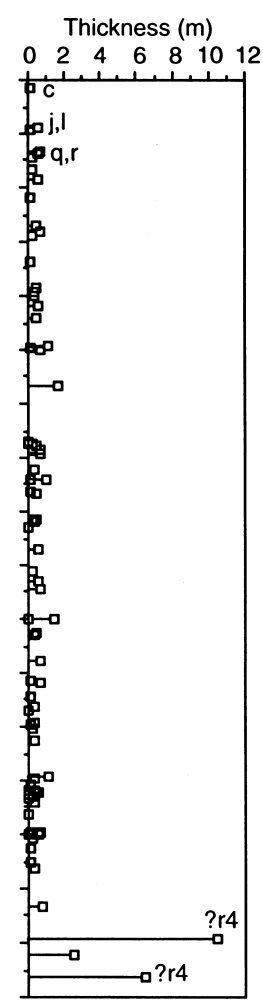

c) Calcareous turbidites

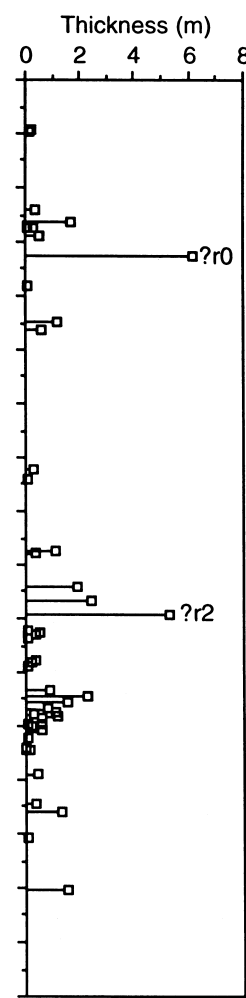

d) Intermediate or undifferentiated turbidites

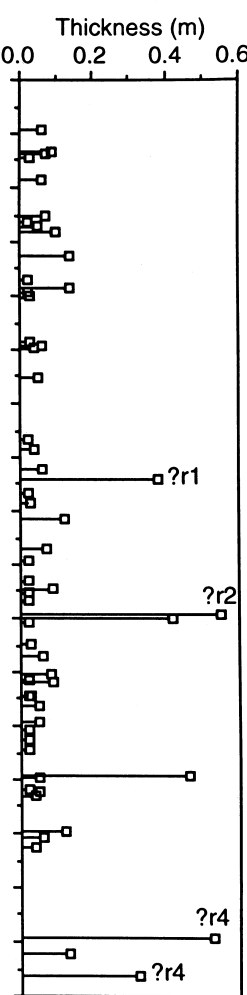

e) Turbidite sands

Figure 8. Diagram showing bed thickness vs. depth for each turbidite type and for sand layers in the sediment sequence recovered at Site 950 . Turbidite/sand thickness is not corrected for compaction effects. Boundaries of the seismic units (depth in mbsf, converted from twt) and the JOIDES Resolution cross-site seismic profile are shown alongside. Possible correlation between some of the thicker units and particular seismic reflectors are indicated. Letters $b$ to $r=s p e c i f i c$ turbidites described by Weaver and Rothwell (1987) and Rothwell et al. (1992). 


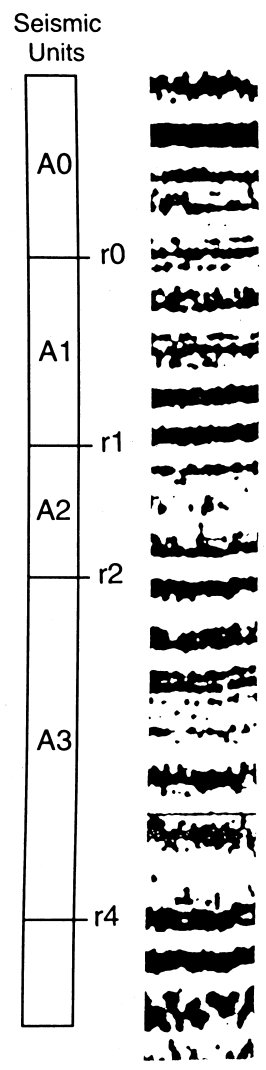

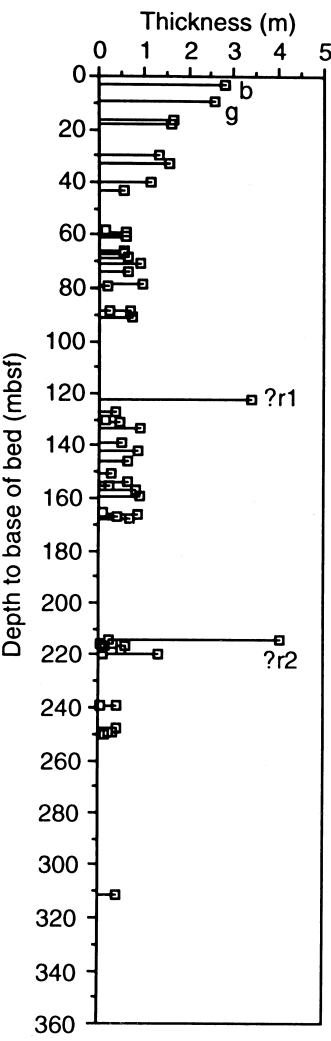

a) Volcanic turbidites

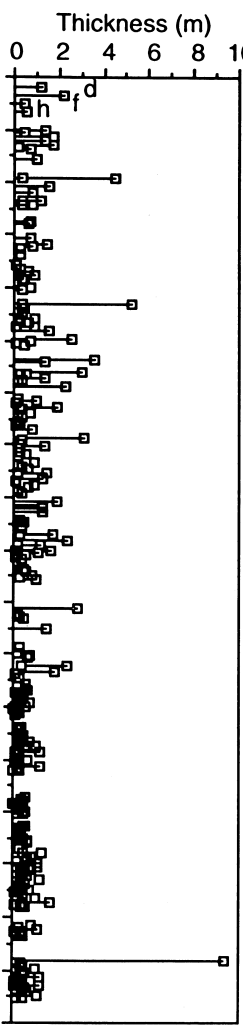

b) Organic turbidites

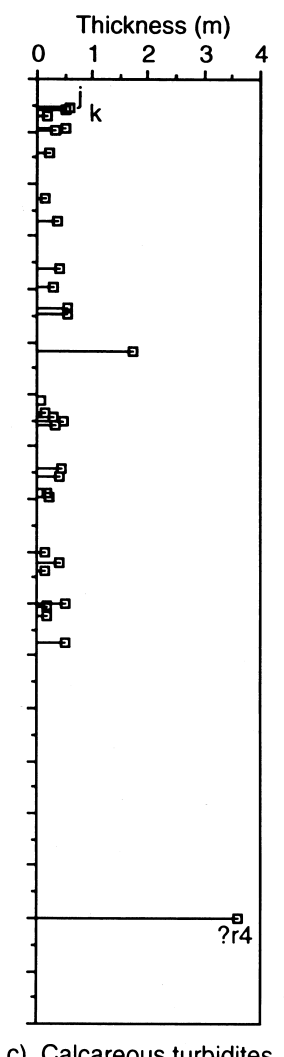

c) Calcareous turbidites

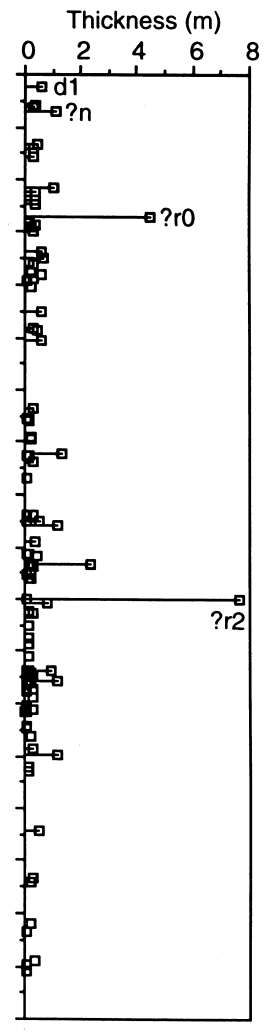

d) Intermediate or undifferentiated turbidites
Thickness ( $m$ )

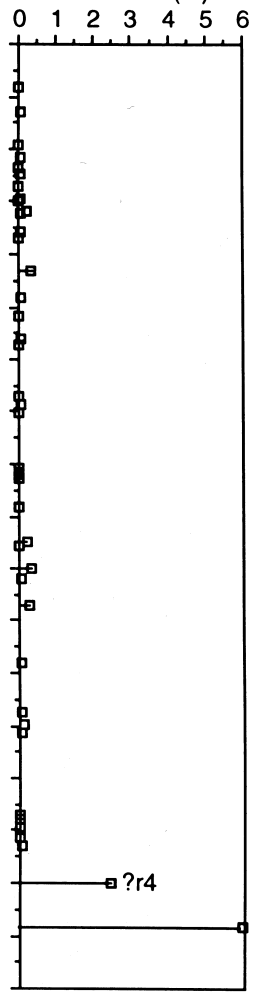

e) Turbidite sands

Figure 9. Diagram showing bed thickness vs. depth for each turbidite type and for sand layers in the sediment sequence recovered at Site 951. Turbidite/sand thickness is not corrected for compaction effects. Boundaries of the seismic units (depth in mbsf, converted from twt) and the JOIDES Resolution cross-site seismic profile are shown alongside. Possible correlation between some of the thicker units and particular seismic reflectors are indicated. Letters $\mathrm{b}$ to $\mathrm{n}=\mathrm{specific}$ turbidites described by Weaver and Rothwell (1987) and Rothwell et al. (1992).

biostratigraphic data from Howe and Sblendorio-Levy, Chap. 29, this volume), we can derive estimates of the accumulation rates (in $\mathrm{m} /$ m.y.) for the sediments within the seismic units (see Table 3).

\section{DISCUSSION}

Seismic reflectors are generated by impedance contrasts within the subsurface, usually at unconformities or major changes in lithology. In some circumstances, reflections can also occur at interfaces with relatively minor lithologic changes or be caused by a change in the physical properties of sediments (density), which may not reflect changes in lithology. The top and bottom interfaces of a lithologic bed could give rise to reflectors, providing the bed is at least one wavelength thick. However, quite thin beds can produce strong reflections, down to one-quarter wavelength or less, if there is constructive interference between the energy returned from the top and base of a bed (McQuillin et al., 1979). Furthermore, because impedance contrasts in sediment piles usually occur over shorter vertical distances than the seismic wavelength, the reflections observed may be, in part, composites resulting from a number of component reflections and interference effects. It is possible for lithology to change without a corresponding change in acoustic impedance; conversely, impedance may change without any major change in lithology (Sheriff and Geldart, 1995; Hardage, 1985). However, although the genesis of reflections can be complex and, in pelagic sequences, it has been demonstrated that reflectors can be generated through the interference of many small layers, or from variation in calcium carbonate content
(Mayer, 1979, 1980), most reflections are commonly considered to correspond to significant lithologic changes or boundaries associated with impedance differences.

The 80 -in ${ }^{3}$ water gun used by the JOIDES Resolution has an optimal frequency range of $8-62 \mathrm{~Hz}$, although significant power is produced above $62 \mathrm{~Hz}$. A water gun frequency of $50 \mathrm{~Hz}$ would give a wavelength of $\sim 30 \mathrm{~m}$, a one-quarter wavelength would, therefore, be $7 \mathrm{~m}$, which one might expect to be close to the limit of individual bed resolution on the seismic records, although, as discussed above, reflector generation is complex, and quite thin beds may give rise to reflectors. However, the seismic signal is attenuated at depth, and this will preferentially decrease the higher frequencies and hence reduce potential resolution (A. Klaus, pers. comm., 1996).

Drilling on the Madeira Abyssal Plain at Sites 950 through 952 allows the probable identity of the previously described, conspicuous basinwide seismic reflectors to be determined. The most conspicuous seismic reflector seen on seismic profiles is $\mathrm{r} 4$, which marks the base of seismic Unit A3 and, hence, of the upper stratified series (previously interpreted as the base of the turbidite sequence by Searle, 1987), with clear unconformity. Reflector 4 lies at $390 \mathrm{~ms}$ at Site 950. The excellent sonic log obtained in Hole 950A shows this to correlate with a depth of $\sim 330$ mbsf (Schmincke, Weaver, Firth, et al., 1995), assuming that the velocity function is correct. Although this interval was one of very poor core recovery at Site 950 , several intervals of a distinctive massive calcarenite were recovered. These consisted of semiconsolidated to unconsolidated structureless muddy silty sand containing sand-sized carbonate grains mixed with volcanic debris of middle Miocene age. The downhole wireline logs showed three 


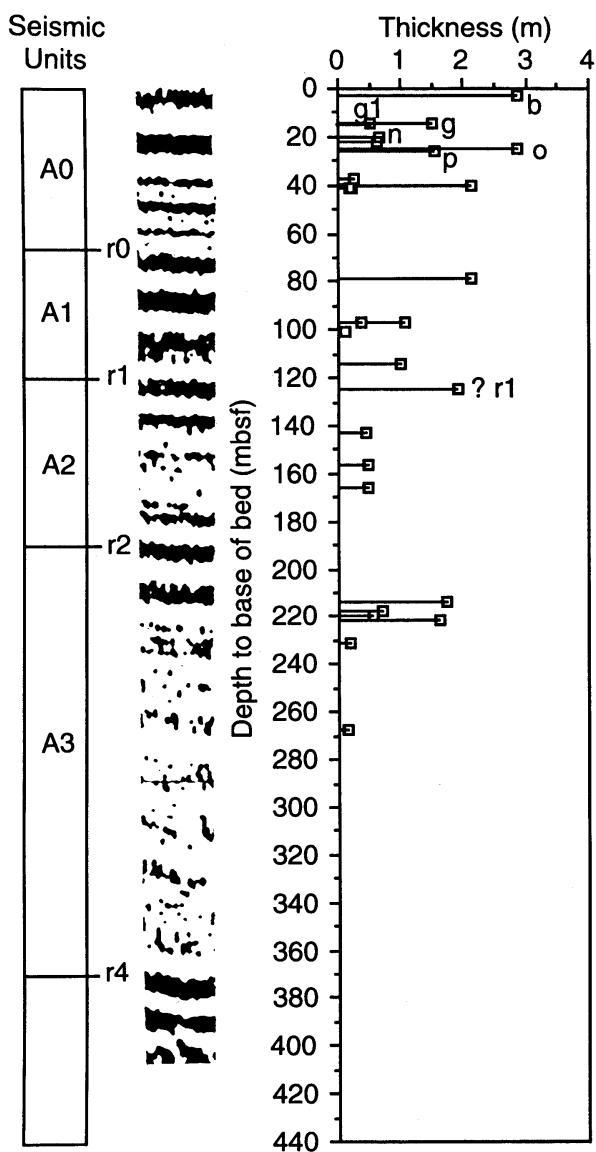

a) Volcanic turbidites

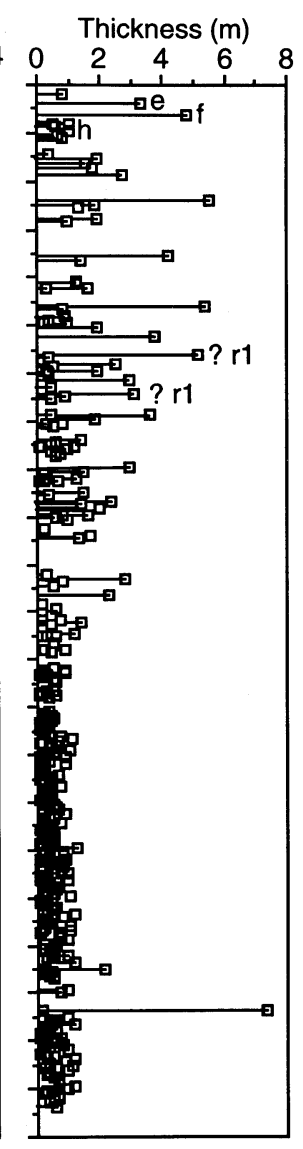

b) Organic turbidites

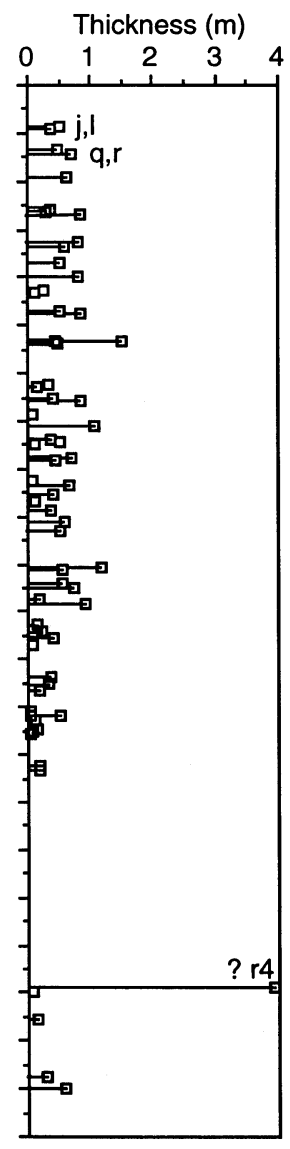

c) Calcareous turbidites

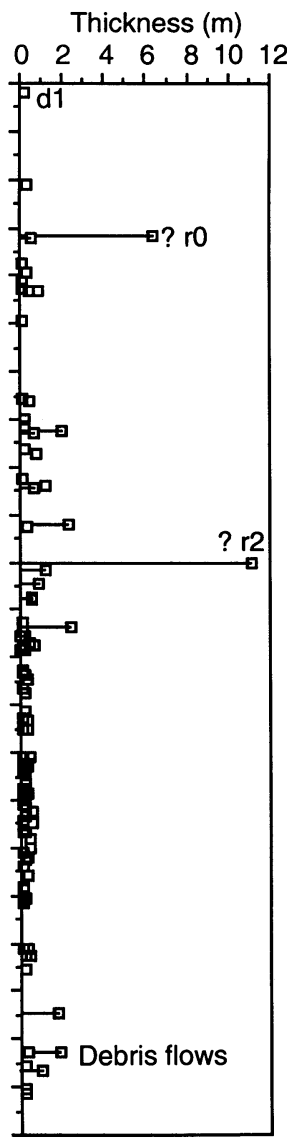

d) Intermediate or undifferentiated turbidites

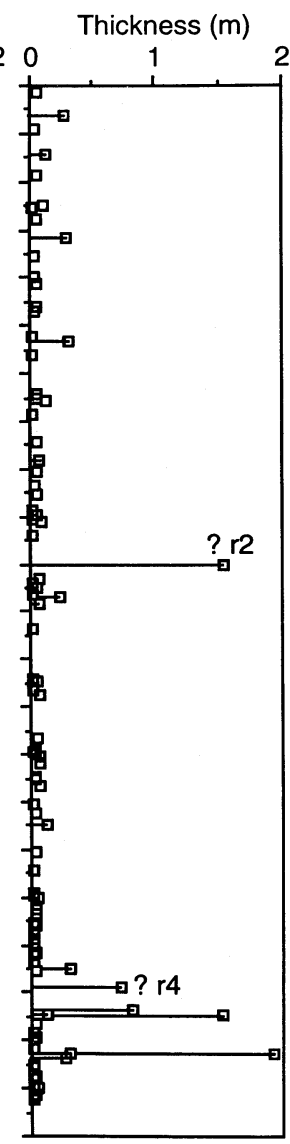

e) Turbidite sands

Figure 10. Diagram showing bed thickness vs. depth for each turbidite type and for sand layers in the sediment sequence recovered at Site 952. Turbidite/sand thickness is not corrected for compaction effects. Boundaries of the seismic units (depth in mbsf, converted from twt) and the JOIDES Resolution cross-site seismic profile shown alongside. Possible correlation between some of the thicker units and particular seismic reflectors are indicated. Letters $b$ to $r=$ specific turbidites described by Weaver and Rothwell (1987) and Rothwell et al. (1992).

coarse-grained units within this interval, extending from 308 to 332 mbsf (Schmincke, Weaver, Firth, et al., 1995). Most wireline logs show very sharp offsets at the upper and lower boundaries of this interval (e.g., Fig. 11).

At Site 951, r4 occurs at $400 \mathrm{~ms}$ below the seafloor on seismic profiles; twt to depth conversion gives this as 320 mbsf (Schmincke, Weaver, Firth, et al., 1995). At Site 951, a very distinctive calcareous turbidite $3 \mathrm{~m}$ thick, with a finely laminated silty/sandy base was recovered from between 318.3 and $320.2 \mathrm{mbsf}$ in an otherwise fairly uniform sequence of green, organic-rich turbidite muds. On the seismic line crossing Site 952, r4 occurs at $445 \mathrm{~ms}$, which converts to 370 mbsf (Schmincke, Weaver, Firth, et al., 1995), which, in turn, corresponds to a distinctive calcareous turbidite with a 60 -cm-thick foraminifer basal sand recovered between 373.5 and 377 mbsf. This turbidite directly overlies several thick bedded sands and debris flows as much as $2 \mathrm{~m}$ thick (Fig. 10). This calcareous bed is distinctive at Sites 951 and 952 in that it varies in color from green in its upper part to greenish white at its base. Indeed, it is the only turbidite recovered in the sequence that shows such color variation (Schmincke, Weaver, Firth, et al., 1995). The basal carbonate sand of this turbidite is also distinctive in that it is composed of carbonate grains strongly reminiscent of beach sand, fresh volcanic debris, and pebble-sized green clay rip-up clasts (Lebreiro et al., Chap. 30, this volume). This unit has been correlated among the three drill sites on the basis of its age and distinctive color and composition (Howe and Sblendorio-Levy,
Chap. 29, this volume; Lebreiro et al., Chap. 30, this volume) and has been dated as $\sim 16 \mathrm{Ma}$ on the basis of associated nannofossil stratigraphy (Howe and Sblendorio-Levy, Chap. 29, this volume). The bed has a maximum thickness ( $24 \mathrm{~m})$ at Site 950 . This distinctive calcareous bed comprises three distinct graded units at Site 950 (at 308$318.5,322-324.5$, and 326-332.5 mbsf), but at the other drill sites, only the upper bed was seen. Lebreiro et al. (Chap. 30, this volume) have named this upper bed the "Cruiser turbidite" because of its widespread and distinctive nature. Reflector 4 , therefore, appears to be associated with a distinctive thick, calcareous turbidite of basinwide lateral extent of early to middle Miocene age. The bed has a sandy base, which coarsens toward the west, suggesting emplacement as an enormous sediment gravity flow from this direction. It is directly overlain at all the drill sites by a great thickness $(\sim 60-150 \mathrm{~m})$ of thin and rather uniform organic-rich turbidites (Figs. 8-10). At Site 950, this distinctive calcareous bed marks the base of the turbidite sequence, overlying pelagic red clays. These clays are barren of nannofossils, but thin calcareous turbidites within the red clay sequence contain moderate to highly abundant, moderately wellpreserved nannofossil assemblages. These thin calcareous turbidites are dated to late Eocene-Oligocene in age by Howe and SblendorioLevy (Chap. 29, this volume), on the basis of nannofossil first occurrences (FOs) from turbidites combined with secondary FO events to mark zonal boundaries based on last occurrences (LOs) found to be reworked. 


\section{Site 950}
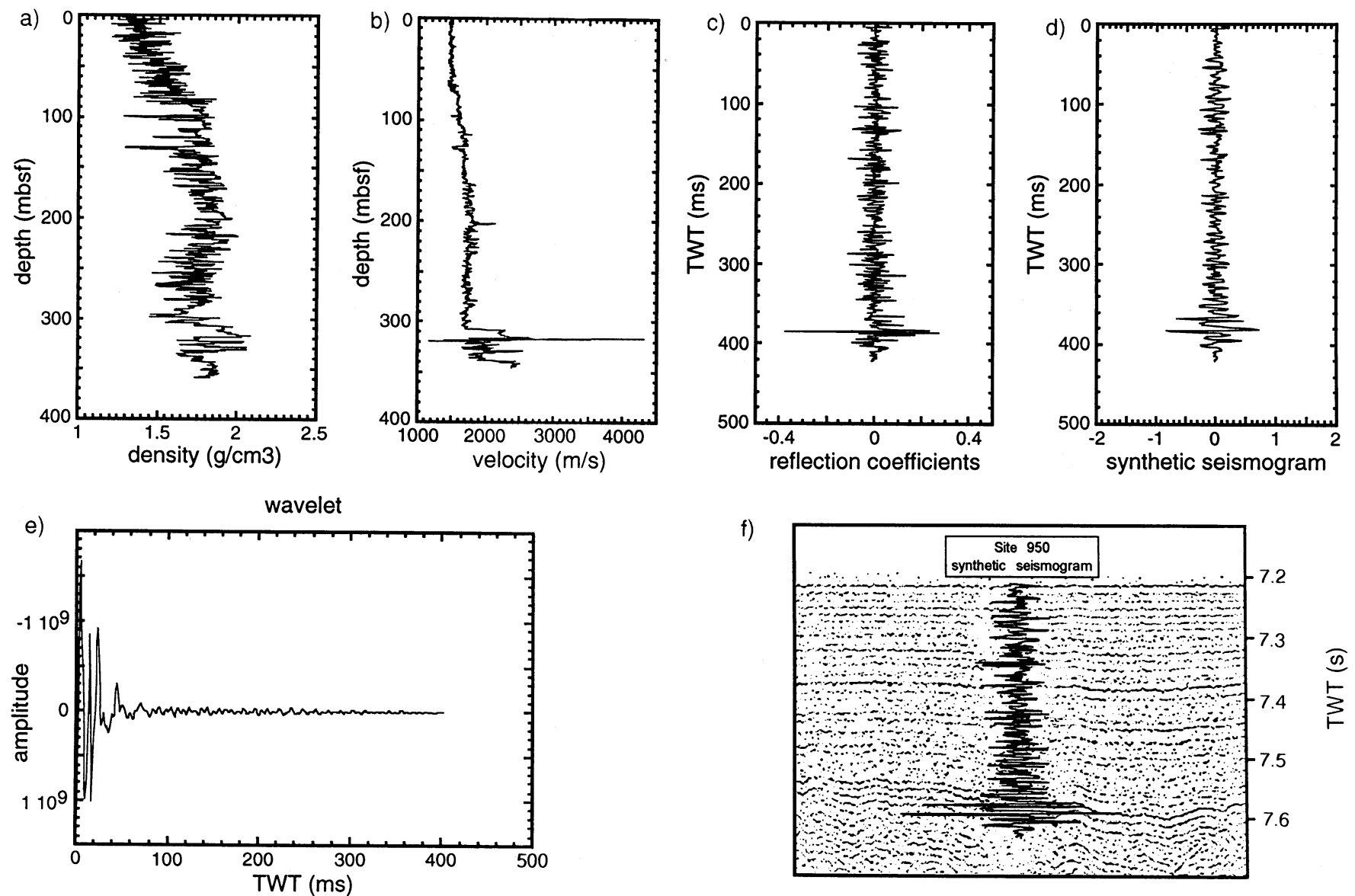

Figure 11. Synthetic seismogram for Site 950. Diagram shows the data used to calculate the synthetic seismogram (see text): (a) downhole density log $\left(\mathrm{g} / \mathrm{cm}^{3}\right)$ from MST, (b) downhole velocity data from MST data (0-150 mbsf) and sonic log data (150-350 mbsf), (c) calculated reflection coefficient, (d) calculated synthetic seismogram, (e) characteristics of the source wavelet, and (f) synthetic seismogram superimposed on the MS Tyro 1982 cross-Site 950 seismic reflection profile.

At Sites 951 and 952 the distinctive Cruiser turbidite does not mark the base of the turbidite sequence. At these two sites, the r4correlated calcareous turbidite overlies a uniform series of thin bedded, organic-rich turbidites of early Miocene age that are very similar in character to the series overlying the Cruiser turbidite at all three drill sites that comprise the lower part of seismic Unit A3. These allochthonous beds below $\mathrm{r} 4$ are interpreted as small, relatively lowvolume flows derived from the Northwest African Continental Margin that initially infilled the Cruiser and Charis Fracture Zone Valleys during the earliest stage of plain formation. Howe and SblendorioLevy (Chap. 29, this volume) demonstrate that at Site 950, a major disconformity exists between the base of the Cruiser turbidite and the Eocene to Oligocene pelagic clays below-the break in time across this disconformity is $\sim 8.3 \mathrm{~m}$.y. (18.2-26.5 Ma). This accounts for the absence of the sequence of thin bedded, organic-rich turbidites seen below the Cruiser turbidite at Sites 951 and 952. Howe and Sblendorio-Levy (Chap. 29, this volume) suggest that the disconformity present at Site 950 was caused by substantial erosion of the underlying sediments during emplacement of the Cruiser turbidite, which appears to be a more proximal deposit at Site 950 than at Sites 951 and 952.

The ages and nature of the other reflectors $(\mathrm{r} 0-\mathrm{r} 3)$ that divide the turbidite sequence from $\mathrm{A} 0$ to $\mathrm{A} 3$ can be considered by examining Figures 8, 9, and 10, which show turbidite thickness (not corrected for compaction) and sand layers (turbidite bases) against depth for each turbidite type at each drill site. The position of these reflectors in milliseconds on the JOIDES Resolution cross-drill site seismic profiles (and the corresponding depth in meters derived from conversion using the sonic logs) are given in Table 2. Most of the individual turbidite beds in the sequences recovered are $<7 \mathrm{~m}$ thick (the approximate one-quarter wavelength of the water gun used by the JOIDES Resolution). However, the most notable exception is a conspicuous pale gray turbidite, almost $10 \mathrm{~m}$ thick, of "intermediate" type recovered between 189.00 and $198.6 \mathrm{mbsf}$ at Site 952 . This has a sandy base $1.5 \mathrm{~m}$ in thickness and is late Miocene in age ( 5.9 Ma; (Howe and Sblendorio-Levy, Chap. 29, this volume). This bed appears coincident with the depth of Reflector 2 on the cross-site seismic reflection profile (Table 2). This bed (although reduced to $\sim 6 \mathrm{~m}$ in thickness) also occurs at similar depth at the other drill sites and, again, correlates well with the position of Reflector 2 at these drill sites (Table 2; Figs. 8, 9). A prominent reflector in the upper part of A3 (at 215-220 mbsf at the three drill sites; Figs. 8-10), just below the position of $\mathrm{r} 2$ as calculated from the velocity data, appears to correlate with a discrete "packet" of volcanic turbidites. It is conceivable that these beds may be, or contribute to, Reflector r2, rather than the thick "intermediate" turbidite above. Reflector 0 , which marks the base of the Pleistocene section (Table 1), also appears to correlate well at all sites with a 6-m-thick turbidite of "intermediate" character, dated at 


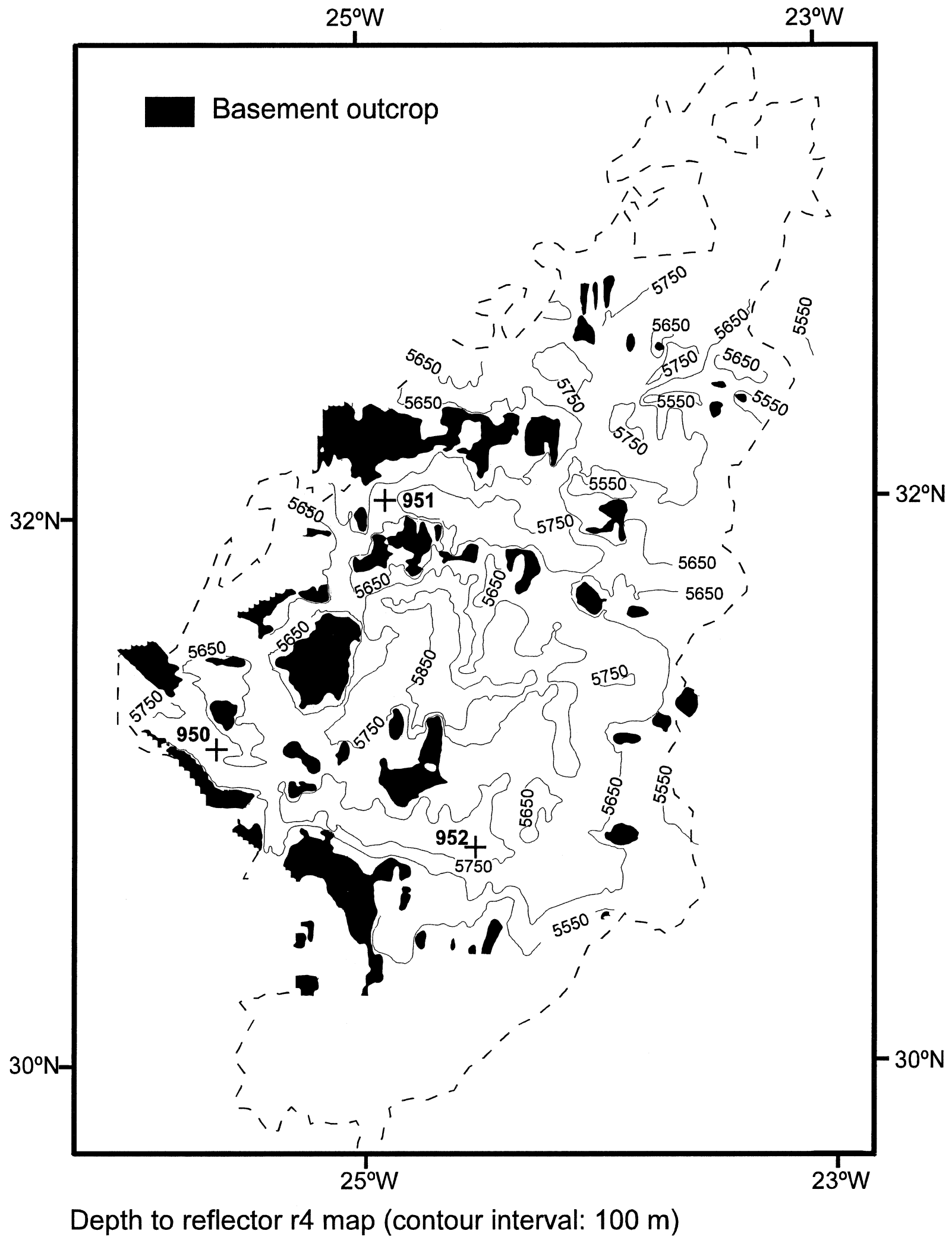

Figure 12. Total depth to $\mathrm{r} 4$ contour map (contour interval $100 \mathrm{~m}$ ). Boundary of abyssal plain (ponded turbidites) shown by dashed line (Universal Transverse Mercator projection) 


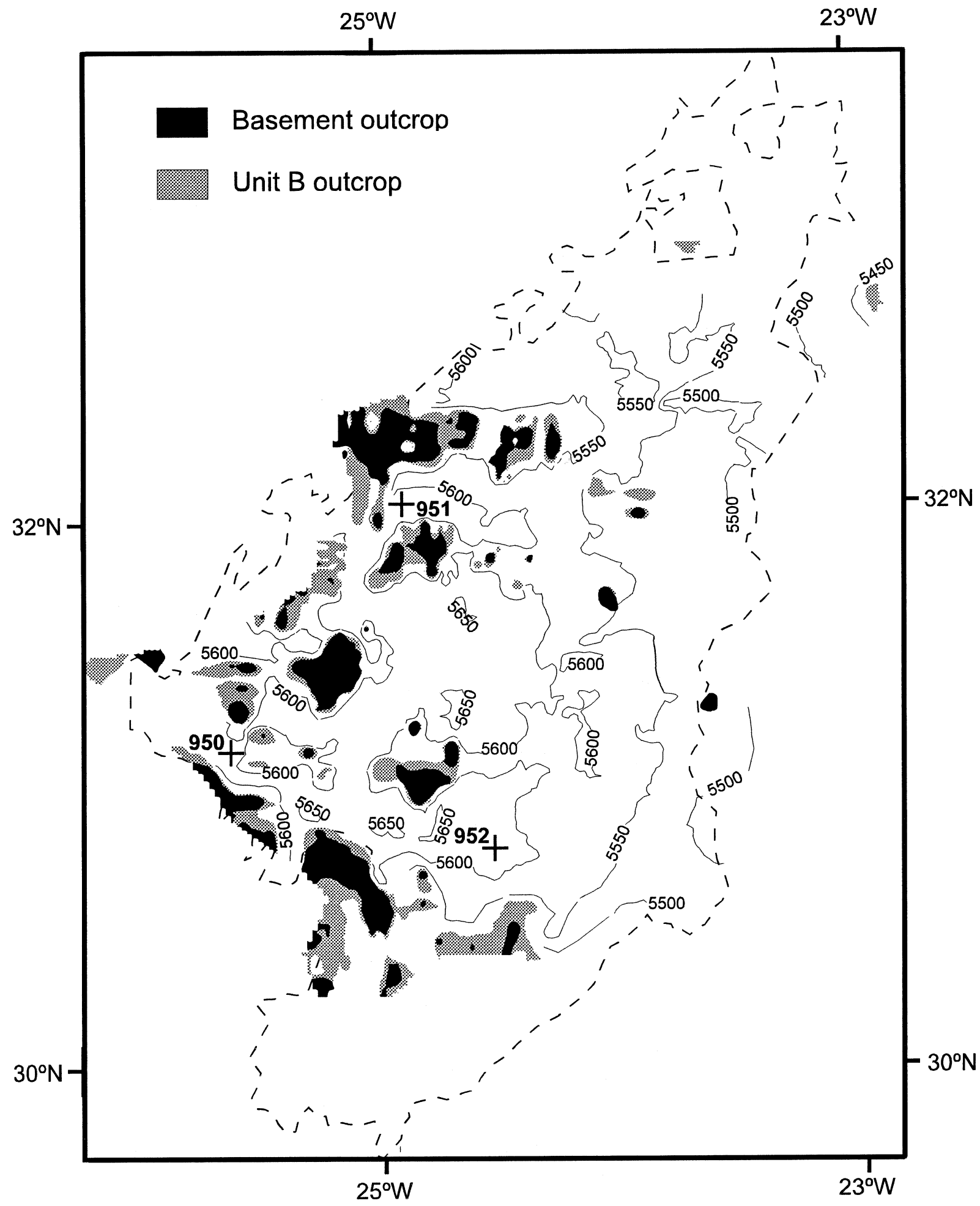

Depth to reflector $\mathrm{r} 2$ map (contour interval: $50 \mathrm{~m}$ )

FIgure 13. Total depth to $\mathrm{r} 2$ contour map (contour interval $50 \mathrm{~m}$ ). Boundary of abyssal plain (ponded turbidites) shown by dashed line (Universal Transverse Mercator projection). 


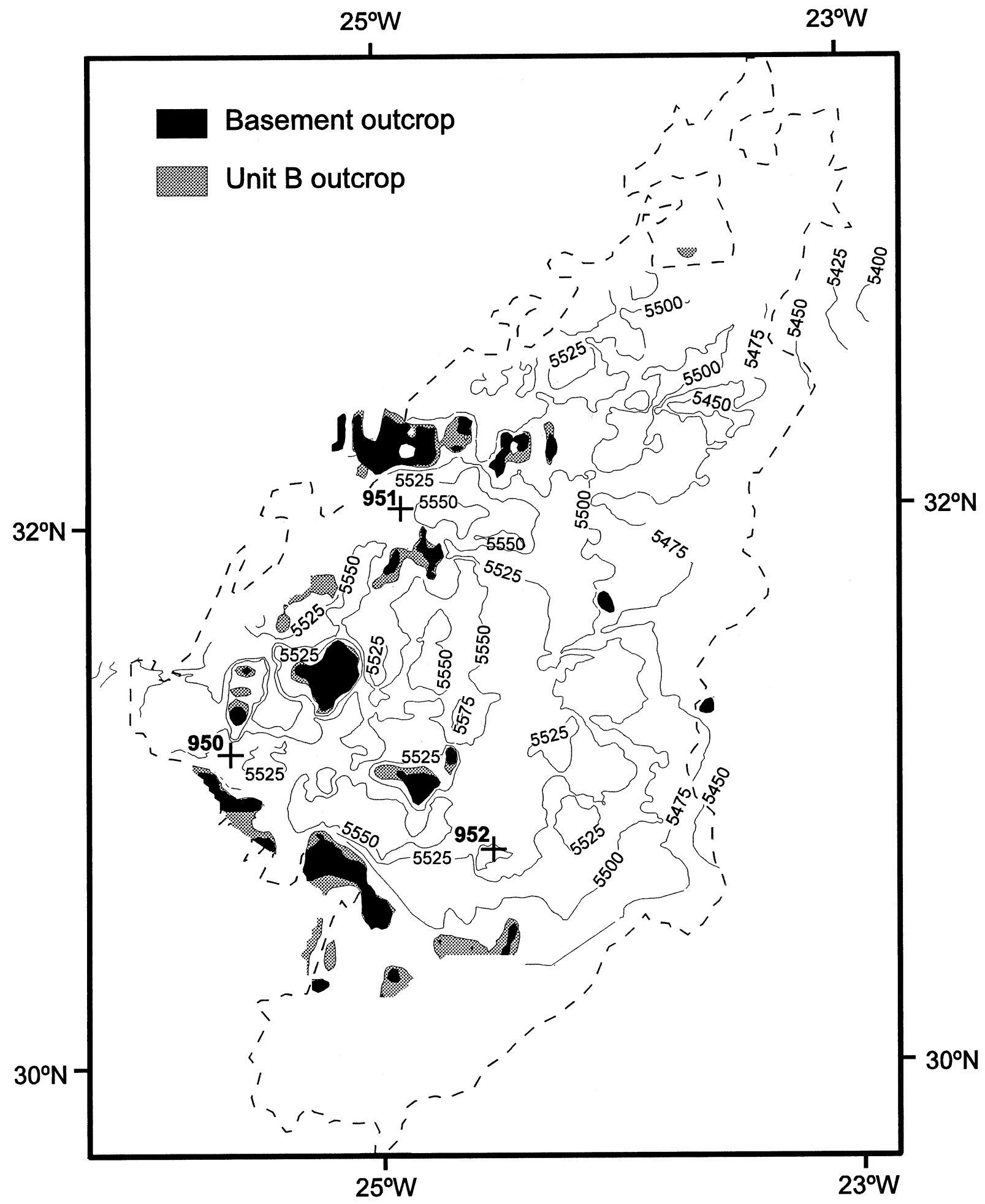

Depth to reflector 1 map (contour: $25 \mathrm{~m}$ )

Figure 14. Total depth to $\mathrm{r} 1$ contour map (contour interval $25 \mathrm{~m}$ ). Boundary of abyssal plain (ponded turbidites) shown by dashed line (Universal Transverse Mercator projection). 


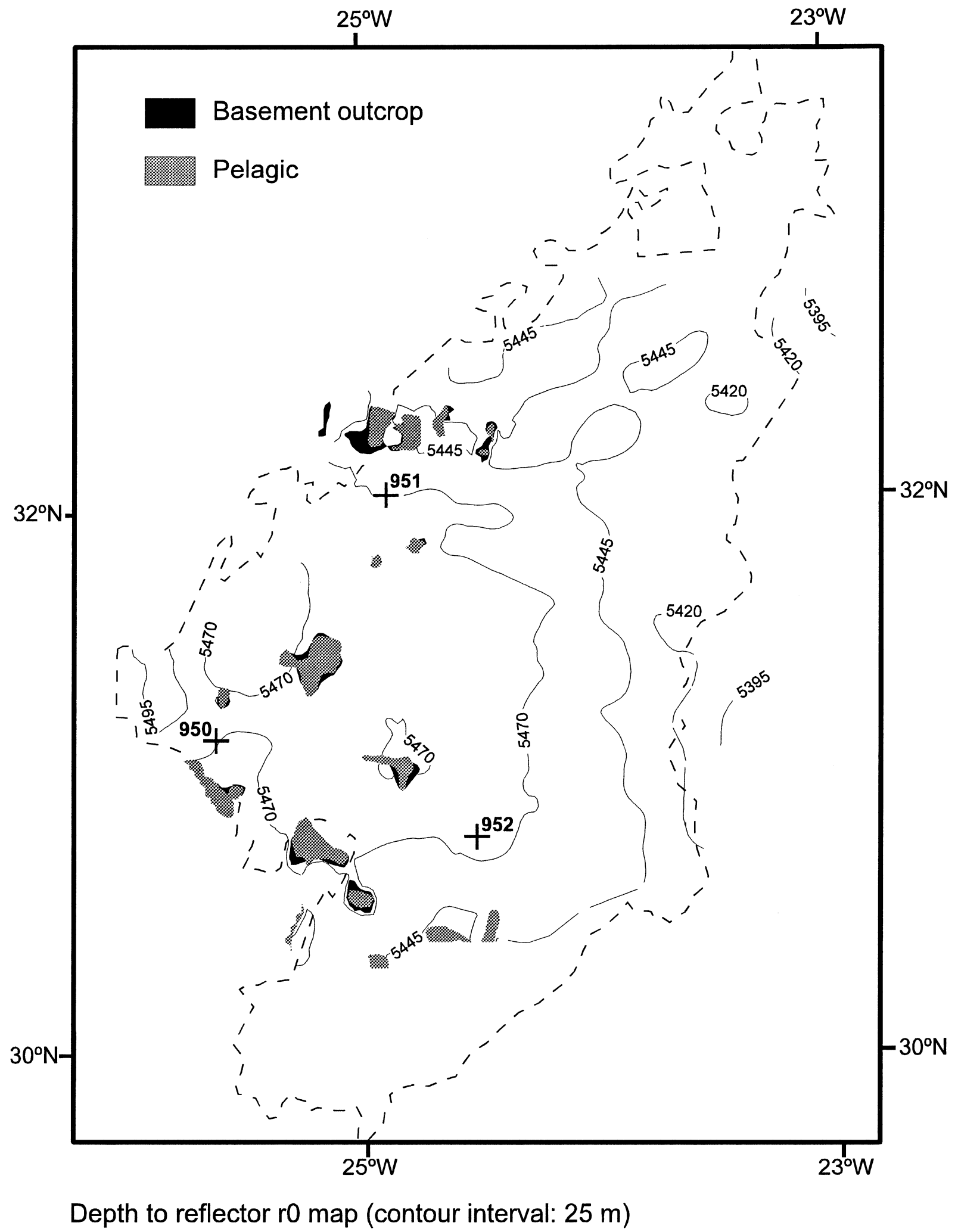

Figure 15. Total depth to r0 contour map (contour interval $25 \mathrm{~m}$ ). Boundary of abyssal plain (ponded turbidites) shown by dashed line (Universal Transverse Mercator projection). 


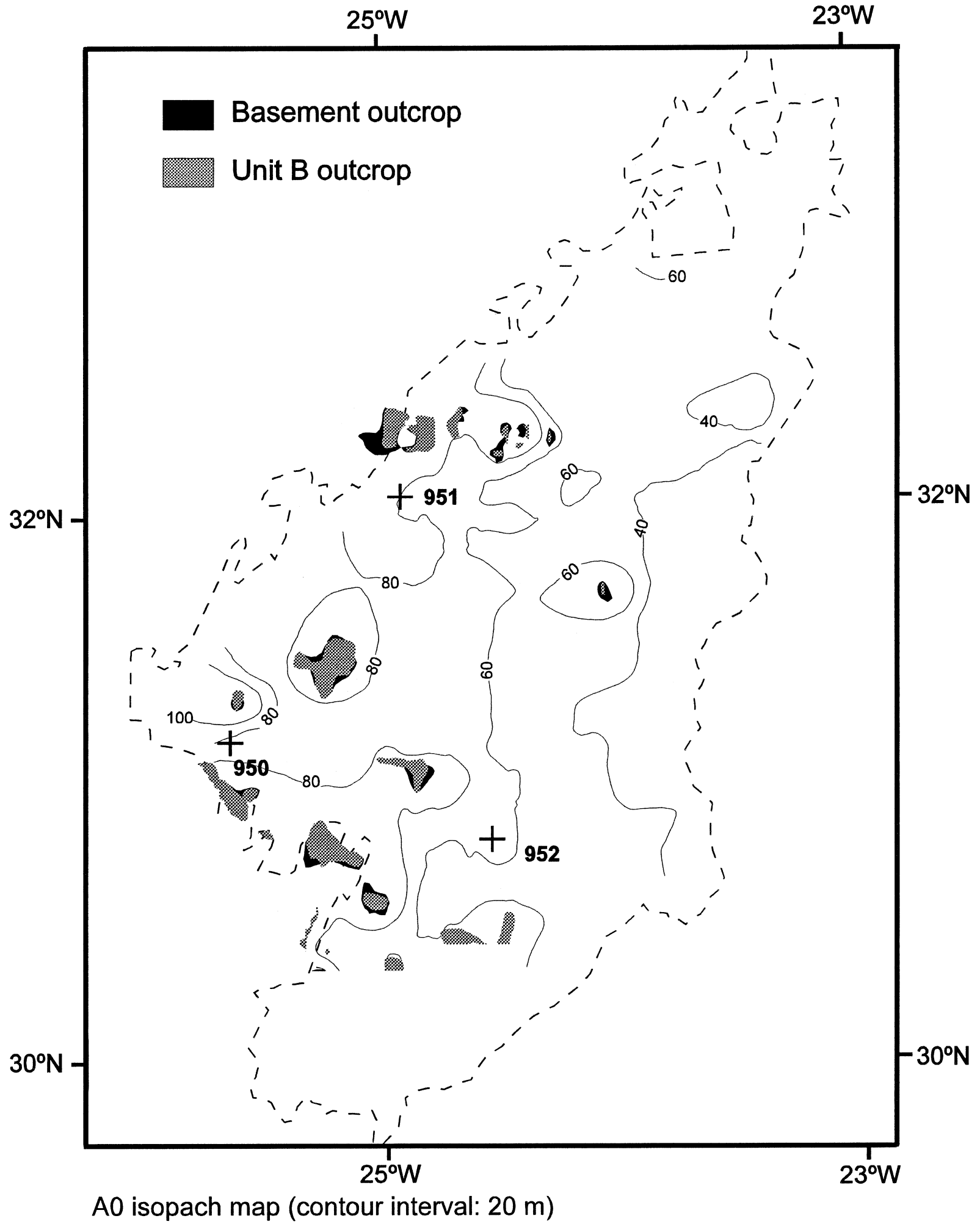

Figure 16. Isopach map of Unit A0 (Pleistocene sequence). Contour interval is $20 \mathrm{~m}$. Boundary of abyssal plain (ponded turbidites) shown by dashed line (Universal Transverse Mercator projection). 


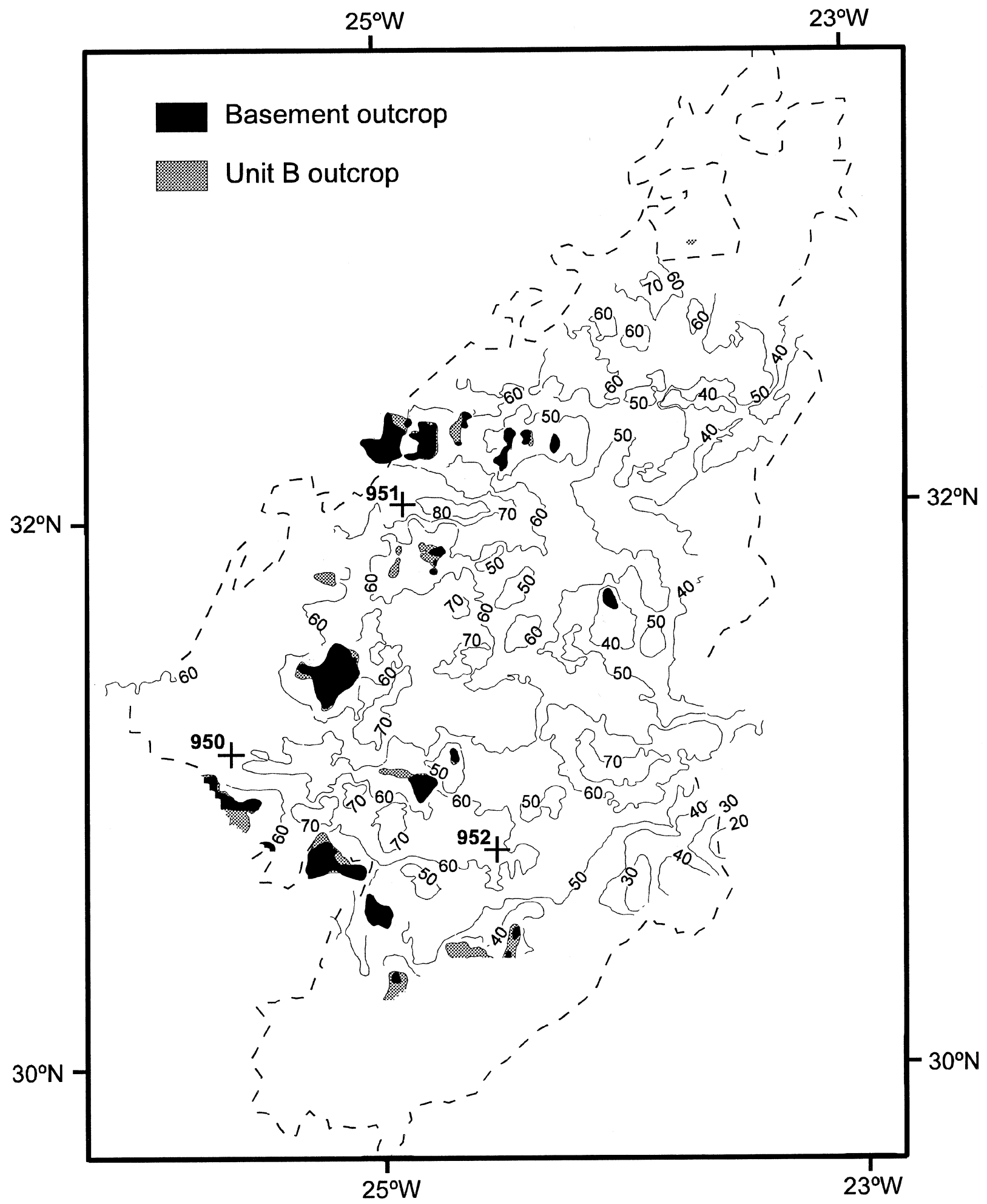

A1 isopach map (contour interval: $10 \mathrm{~m}$ )

Figure 17. Isopach map of Unit A1 (late Pliocene sequence). Contour interval is $10 \mathrm{~m}$. Boundary of abyssal plain (ponded turbidites) shown by dashed line (Universal Transverse Mercator projection). 


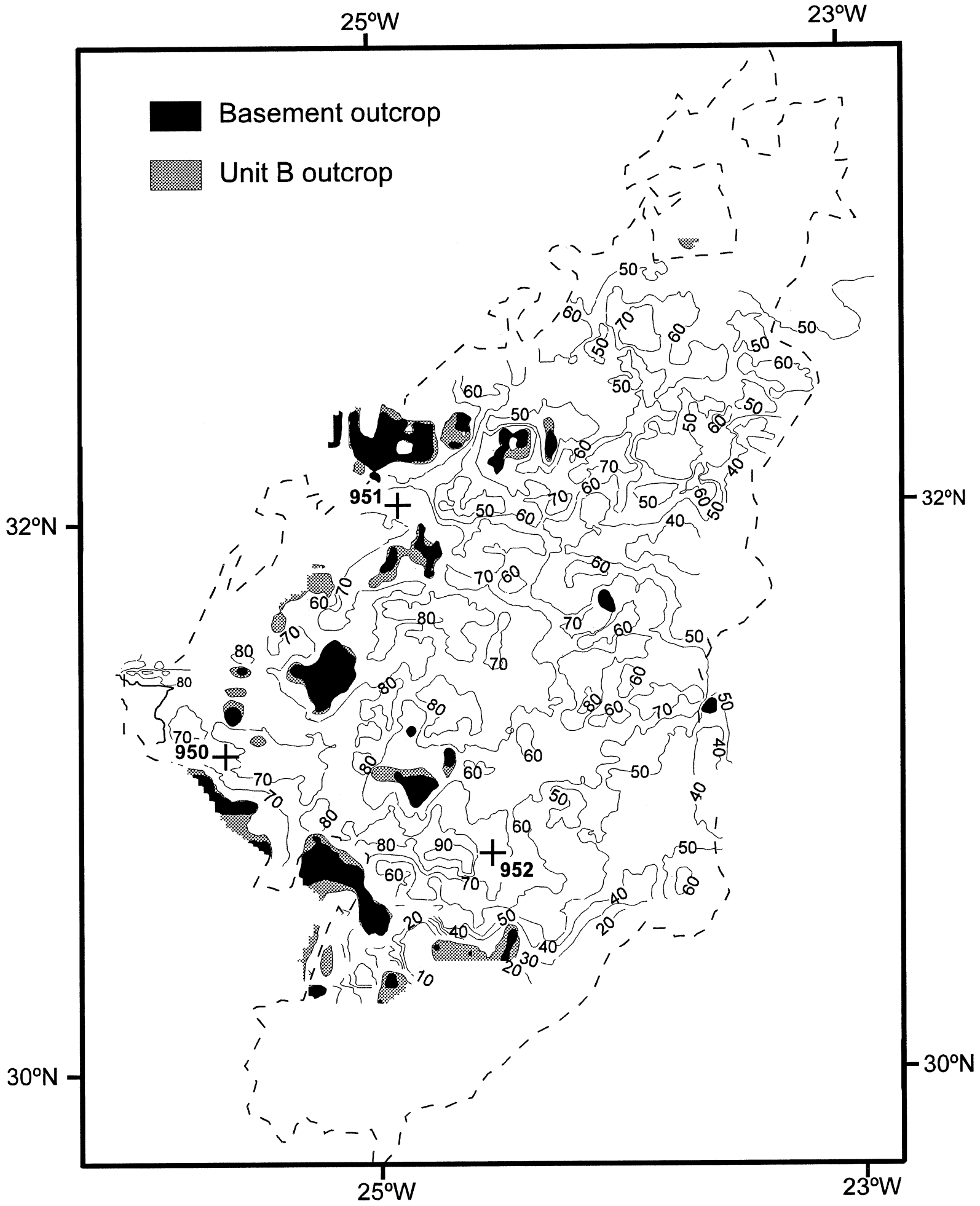

A2 isopach map (contour interval: $10 \mathrm{~m}$ )

Figure 18. Isopach map of Unit A2 (early Pliocene-late Miocene sequence). Contour interval is $10 \mathrm{~m}$. Boundary of abyssal plain (ponded turbidites) shown by dashed line (Universal Transverse Mercator projection). 


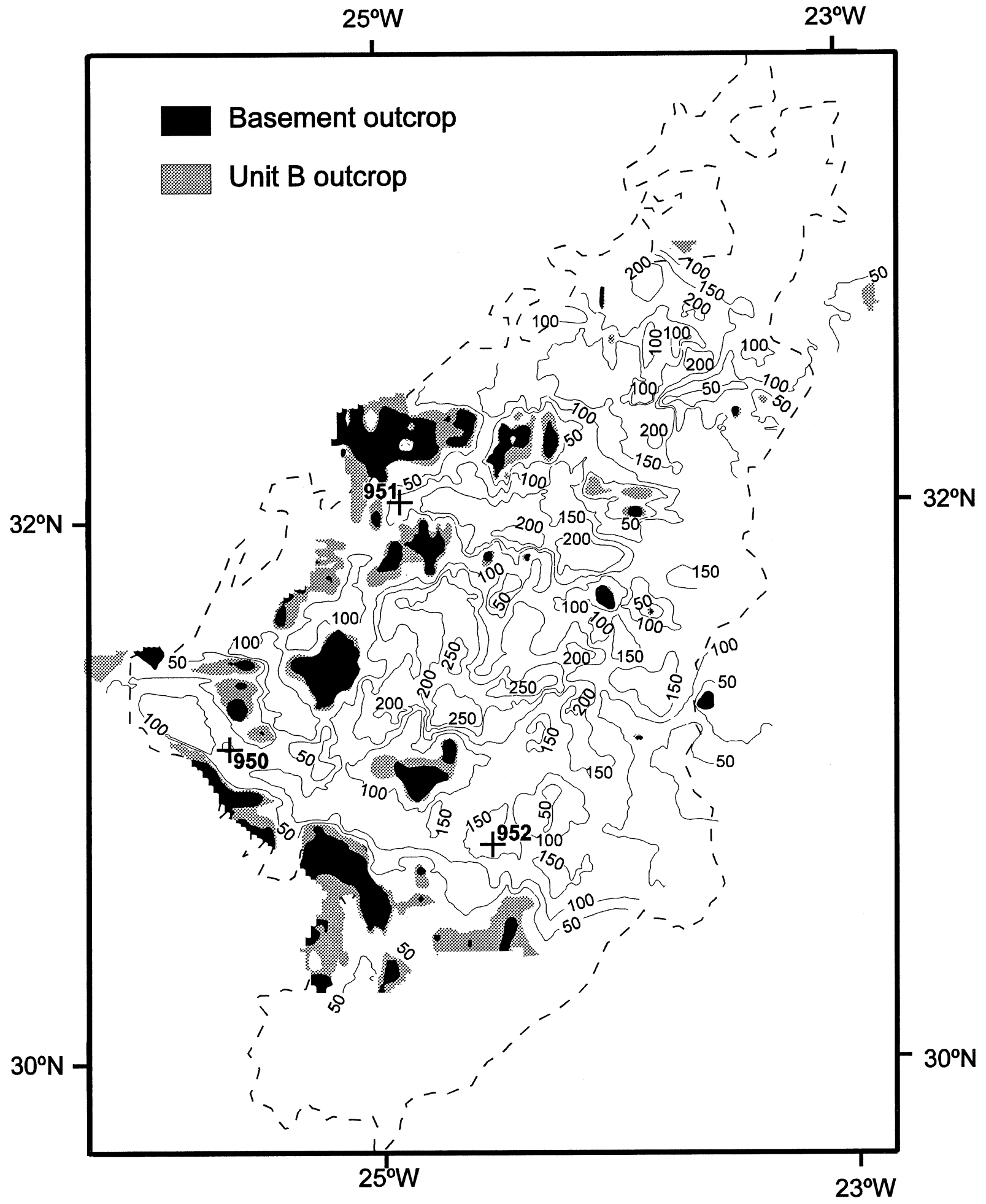

A3 isopach map (contours: $50 \mathrm{~m}$ )

Figure 19. Isopach map of Unit A3 (late-middle Miocene). Contour interval is $50 \mathrm{~m}$. Boundary of abyssal plain (ponded turbidites) shown by dashed line (Universal Transverse Mercator projection). 
Table 3. Calculated volumes for Seismic Units AO through A3 and gross accumulation rates for each seismic unit.

\begin{tabular}{|c|c|c|c|c|c|c|c|c|}
\hline Seismic Unit & $\begin{array}{l}\text { Age of } \\
\text { Sediments } \\
\text { (Ma) }\end{array}$ & $\begin{array}{c}\text { Area for } \\
\text { calculated volume } \\
\left(\mathrm{km}^{2}\right)\end{array}$ & $\begin{array}{l}\text { Present volumes (not } \\
\text { corrected for compaction) } \\
\left(\mathrm{km}^{3}\right)\end{array}$ & $\begin{array}{l}\text { Average } \\
\text { thickness } \\
\text { (m) }\end{array}$ & $\begin{array}{c}\text { Equivalent } \\
\text { accumulation rate } \\
(\mathrm{m} / \mathrm{Ma})\end{array}$ & $\begin{array}{l}\text { Volumes (corrected for } \\
\text { compaction) } \\
\left(\mathrm{km}^{3}\right)\end{array}$ & $\begin{array}{c}\text { Decompacted } \\
\text { average thickness } \\
\text { (m) }\end{array}$ & $\begin{array}{c}\text { Gross } \\
\text { accumulation rate } \\
(\mathrm{m} / \mathrm{Ma})\end{array}$ \\
\hline A0 & $0.0-1.9$ & 43,648 & 2,380 & 55 & 29 & 3,060 & 70 & 37 \\
\hline $\mathrm{A} 1$ & $1.9-3.6$ & 41,272 & 2,386 & 58 & 34 & 3,690 & 88 & 52 \\
\hline A2 & $3.6-5.9$ & 37,427 & 2,340 & 68 & 30 & 4,270 & 114 & 50 \\
\hline A3 & $5.9-16$ & 37,046 & 4,480 & 118 & 12 & 8,160 & 214 & 21 \\
\hline
\end{tabular}

Note: Calculated volumes that have and have not been corrected for compaction are shown.

1.9 Ma, based on associated nannofossil stratigraphy (Howe and Sblendorio-Levy, Chap. 29, this volume; Figs. 8-10). The identity of $\mathrm{r} 1$ is more obscure, although a 3-m-thick volcanic-rich turbidite of early late Pliocene age (dated $\sim 3.6 \mathrm{Ma}$ ), occurs at the corresponding depth at all three sites. This overlies several volcanic-rich turbidites, and these, too, may contribute to reflection formation. Reflector 3 was originally identified by Duin and Kok (1984) as an acoustic reflector in the acoustically transparent sediment unit between $\mathrm{r} 4$ and r2 (i.e., within seismic Unit A3). This reflector has a very low amplitude in some places and is commonly difficult to distinguish. We do not consider this reflector to be of regional importance and, thus, have not sought to identify it.

One might expect little impedance contrast between different beds because they are so similar in texture and the bulk of the units are composed of coccolith plates and clay. Many turbidites have silty or sandy bases, but these are rarely more than $0.5 \mathrm{~m}$ thick (Figs. 810). However, many turbidites lack coarser grained bases, and E3 division mud of one turbidite commonly overlies pelagic ooze, clay, or E3 division muds of another turbidite (Schmincke, Weaver, Firth, et al., 1995). There appears to be a clear correspondence between the occurrence of numerous, strong parallel horizontal to subhorizontal reflectors in the uppermost seismic Unit A0 and the occurrence of thick, volcanic-rich turbidites within this interval (Figs. 8-10). Packets of strong reflectors in the lower part of A1, the upper part of A2, and the upper part of A3 also show correspondence with packets of volcanic-rich turbidites, although individually, these are rarely more than a meter in thickness. Conversely, there is good correspondence between acoustically transparent intervals in the lower parts of Units $\mathrm{A} 2$ and $\mathrm{A} 3$ and intervals of almost exclusively thin bedded $(<2 \mathrm{~m})$, organic-rich turbidite muds.

Because of progressive burial of the original ridge-flank topography and Cruiser and Charis Fracture Zone Valleys by turbidites derived largely from the Northwest African shelf and from the flanks of the Canary Islands, the total depth maps to reflectors r0 to r4 (Figs. 12-15) show a progressive levelling of the plain throughout the Neogene. As the turbidites are forced to pond, they preferentially fill the deeper topography. Large-volume flows, which are particularly common in the Pliocene/Pleistocene sequence, can laterally cover the entire basin, but the extent of smaller volume flows is controlled by their source and microtopography. Smaller volume turbidites commonly fill in lows in plain microtopography, which itself is determined by the lateral extent of previously emplaced beds (Rothwell et al., 1992). The infilling of microtopographic lows by smaller volume turbidites also aids in the gradual leveling of the plain over time. The fracture zone valleys remain as more or less distinct features, although with progressively subdued relief, until the late to middle Pliocene. The present form of the plain appears to be a late Neogene to Quaternary feature.

The isopach maps for seismic Units A0 through A3 (Figs. 16-19) show that Unit A3 (late to middle Miocene) has a variable thickness over the plain but is generally $100-200 \mathrm{~m}$ thick. This unit reaches its greatest thickness $(200-250 \mathrm{~m})$ in the central part of the plain. Seismic Unit A2 (late Miocene to early Pliocene) is a much thinner unit but is more constant in thickness, typically $60-80 \mathrm{~m}$ thick over the central part of the plain. Seismic Unit A1 (late Pliocene in age) is of similar thickness $(\sim 50-60 \mathrm{~m})$ and shows only relatively minor variation in thickness across the plain. Seismic Unit A0 shows more variation (Fig. 16), ranging from $40 \mathrm{~m}$ in thickness in the eastern, more proximal, part of the plain, to $80-100 \mathrm{~m}$ thickness in the western distal plain. This east-to-west thickening of the Pleistocene sequence is probably caused by the progressive infilling of the more proximal lows and depressions on the plain during the Pliocene, forcing largevolume Pleistocene flows to pond in more distal lows in the western part of the plain.

The volume of sediments within the individual seismic Units A0 through A3 can be calculated from the DTMs of the upper and lower limits of the unit. These volumes must be regarded as minimum values because the calculations are constrained by the seismic coverage. The present volumes, which are not corrected for compaction, are calculated as $2380 \mathrm{~km}^{3}$ for $\mathrm{A} 0,2386 \mathrm{~km}^{3}$ for $\mathrm{A} 1,2340 \mathrm{~km}^{3}$ for A2, and $4480 \mathrm{~km}^{3}$ for $\mathrm{A}^{3}$. If we consider that seismic Unit $\mathrm{A} 0$ was deposited between 0 and 1.9 Ma, Unit A1 between 1.9 and 3.6 Ma, Unit A2 between 3.6 and $5.9 \mathrm{Ma}$, and Unit A3 between 5.9 and $16 \mathrm{Ma}$ (Howe and Sblendorio-Levy, Chap. 29, this volume), we can estimate the volume per million years that was deposited within each unit, and because we know the area for which volume calculations have been made, we can calculate the accumulation rates for each seismic unit (in terms of meters of sediment deposited per million years). These data are presented in Table 3, together with the equivalent values corrected for compaction using the method of Van Hinte (1978) discussed above. It can be seen that since the inception of the abyssal plain in the middle Miocene (16 Ma), a minimum of $19,180 \mathrm{~km}^{3}$ of sediment (turbidites and pelagites) has been deposited. Assuming a turbidite volume/pelagite volume ratio of 10:1 (see Rothwell et al., 1992), then a minimum of $17,400 \mathrm{~km}^{3}$ of turbidites have been emplaced onto the abyssal plain since its inception.

The ages, gross accumulation rates, volumes, and lithologies of the seismic units are summarized in Table 4, together with a corresponding summary of the development of Canary Island volcanism and sea-level fluctuation (from Haq et al., 1987) over the time of deposition of the turbidite sequence. The emplacement of volcanic turbidites begins abruptly at $\sim 6.5 \mathrm{Ma}$ and increases in intensity, with the shield-building phases of the western Canary Islands (Hierro, La Palma, Gomera, and Tenerife). The resulting landslides on the flanks of these islands gave rise to the volcanic-rich turbidites recovered from the plain sequence. Turbidites resulting from slope failures on the flanks of the eastern Canary Islands (Gran Canaria, Fuerteventura, and Lanzarote) were presumably deposited mainly on the broad continental rise and failed to reach the abyssal plain. The first emplacement of volcanic-rich turbidites onto the plain appears to correlate with a period of initially rising $(\sim 5.9-6.0 \mathrm{Ma})$ and then falling sea level during the Messinian (late Miocene; 5.8-5 Ma), which resulted in the isolation of the Mediterranean and the well-documented "salinity crisis" (Hsü et al., 1973). Emplacement of volcanic turbidites has continued to the present day through the period of marked sea-level transgressions and regressions that have characterized the Pliocene and Quaternary periods. Changing sea level may play an important role in the development of structural instability at oceanic volcanoes through peripheral erosion and debuttressing, which when combined with active shield growth, may make volcanic island 
Table 4. Summary of the age, gross accumulation rate, volume, lithology, and main turbidite types of seismic Units A0, A1, A2, and A3.

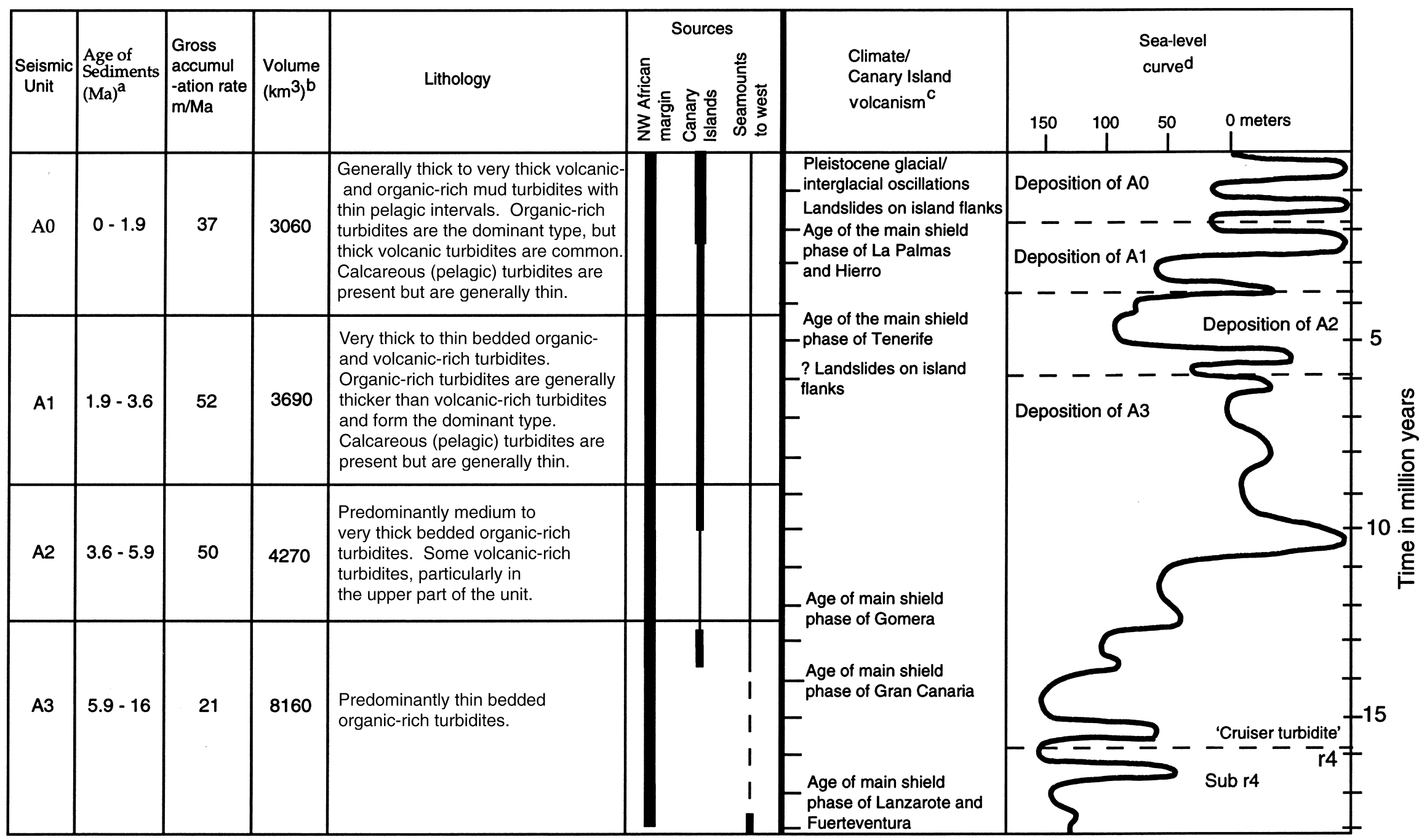

Notes: Thickness of line in "Sources" column indicates the relative supply from different turbidite sources. a Age data from Howe and Sblendorio-Levy (Chap. 29 , this volume). ${ }^{\mathrm{b}}$ Volumes corrected for compaction. ${ }^{\mathrm{c}}$ Data on Canary Islands

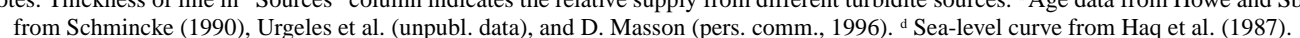


flanks particularly unstable (McGuire, 1996). These factors may have been important in triggering many of the large number of volcanic-rich flows during the Pliocene/Pleistocene. Instability on the Northwest African Continental Margin beneath upwelling cells has been continuous throughout the Neogene, resulting in a steady and relatively continuous flux of organic-rich turbidites to the Madeira Abyssal Plain. Calcareous turbidites, derived from instability on the seamounts and bathymetric highs to the west of the plain, have also been regularly emplaced, but on a much smaller scale, and are more significant in the western part of the plain than in the east.

\section{CONCLUSIONS}

1. Seismic profiles across the Madeira Abyssal Plain show a relatively simple seismic stratigraphy in which an irregular diffractive basement is overlain by five distinctive seismic units, separated by strong continuous, high-amplitude reflectors with basinwide distribution. This pattern reflects a great thickness of ponded turbidites (seismic Units A0-A3) overlying pelagic drape (seismic Unit B).

2. The thick sequence of ponded turbidites (seismic Units A0A3) range from the early middle Miocene to the Holocene and overlies pelagic drape, with marked unconformity forming a regional reflector ( $(\mathrm{r} 4)$. Reflector 4 is correlated with a distinctive calcareous turbidite of early Miocene age (16 Ma) at all drill sites. The bed has a sandy base, which coarsens toward the west, suggesting emplacement as an enormous sediment gravity flow from this direction.

3. Conversion of twt data to depth using shipboard sonic log data suggests that thick volcanic-rich and "intermediate" character turbidites of wide lateral extent commonly correspond to strong seismic reflectors and that acoustically transparent intervals within the seismic units of the Neogene turbidite section correspond to intervals of predominantly organic-rich turbidites.

4. Prominent regional seismic reflectors, which divide the seismic units and have been previously described, can now be identified with reasonable certainty. Reflector 0 , which marks the base of the Pleistocene section, possibly correlates with a 6-m-thick turbidite of "intermediate" character dated at 1.9 Ma. The identity of $\mathrm{r} 1$ is more obscure, although a 3-m-thick volcanic-rich turbidite of early late Pliocene age (3.6 Ma) occurs at the corresponding depth at all drill sites. This bed overlies several volcanic-rich turbidites, and these, too, may contribute to reflection formation. Reflector 2 , a very prominent basinwide reflector within the turbidite sequence, correlates with a conspicuous 10 -m-thick turbidite of "intermediate" type of late Miocene age (dated at 5.9 Ma)

5. The volume of sediments within the individual seismic Units A0 through A3 calculated from the DTMs of the upper and lower limits of the unit give minimum values of sediment accumulation on the plain per unit time. Since the inception of the abyssal plain in the middle Miocene (16 Ma), a minimum of $19,180 \mathrm{~km}^{3}$ of sediment (turbidites and pelagites) has been deposited. This suggests that a minimum of $\sim 17,400 \mathrm{~km}^{3}$ of turbidites have been emplaced onto the abyssal plain since its inception.

\section{ACKNOWLEDGMENTS}

We would like to thank Holger Lykke-Andersen of the University of Aarhus, Derek Bishop of Southampton Oceanography Centre, and Adam Klaus of the Ocean Drilling Program for very helpful discus- sions on water gun resolution. We also thank the shipboard scientific party, the ODP technicians, and the SEDCO drilling crew of Leg 157, during which the drill site data were collected. We are very grateful to Chris Mesdag of the Rijks Geologische Dienst (Netherlands) for allowing us access to the extensive seismic data set collected by RGD from the Madeira Abyssal Plain and for providing us the source wavelet to calculate the synthetic seismogram. Drs. Chris Wilson and Patricia Manley are thanked for their reviews, which improved the manuscript. This work was supported by the European Commission Marine Science and Technology (MAST II) program (Sediment Transport on European Atlantic Margins [STEAM] Project; Grant No. MAS2-CT94-0083). B. Alibés was also funded by Grant GRQ94-95-1026 of the Generalitat de Catalunya.

\section{REFERENCES}

Anderson, D.R. (Ed.), 1980. Proc. 5th Annu. NEA-Seabed Working Group Meeting: Albuquerque, NM (Sandia Natl. Lab.), Rep. SAND80-075.

De Lange, G.J., Jarvis, I., and Kuijpers, A., 1987. Geochemical characteristics and provenance of late Quaternary sediments from the Madeira Abyssal Plain, North Atlantic. In Weaver, P.P.E., and Thomson, J. (Eds.), Geology and Geochemistry of Abyssal Plains. Geol. Soc. Spec. Publ. London, 31:147-165.

Duin, E.J.T., and Kok, P.T.J., 1984. A geophysical study of the Western Madeira Abyssal Plain. Med. Rijks Geol. Dienst, 38-2:67-89.

Duin, E.J.T., and Kuijpers, A., 1983. Geological Studies on Abyssal Plains in the North Atlantic: Contrib. Seabed Working Group Progr. Rept. 1982, Internal Rept.: Haarlem (Rijks Geol. Dienst).

Haq, B.U., Hardenbol, J., and Vail, P.R., 1987. Chronology of fluctuating sea levels since the Triassic. Science, 235:1156-1167.

Hardage, B.A., 1985. Vertical Seismic Profiling, Part A: Principles (2nd ed.): London (Geophysical Press)

Heezen, B.C., Ewing, M., and Ericson, D.B., 1951. Submarine topography in the North Atlantic. Bull. Geol. Soc. Am., 62:1407-1409.

Hsü, K.J., Cita, M.B., and Ryan, W.B.F., 1973. The origin of the Mediterranean evaporites. In Ryan, W.B.F., Hsü, K.J., et al., Init. Repts. DSDP, 13 (Pt. 2): Washington (U.S. Govt. Printing Office), 1203-1231.

Kidd, R.B., Searle, R.C., Weaver, P.P.E., Jacobs, C.L., Huggett, Q.J., Noel, M.J., and Schultheiss, P.J., 1983. King's Trough Flank: geological and geophysical investigations of its suitability for high-level radioactive waste disposal. Inst. Oceanogr. Sci. Rep., 166.

Mayer, L.A., 1979. Deep sea carbonates: acoustic, physical, and stratigraphic properties. J. Sediment. Petrol., 49:819-836.

1980. Deep-sea carbonates: physical property relationships and the origin of high-frequency acoustic reflectors. Mar. Geol., 38:165-183.

Mazzullo, J.M., Meyer, A., and Kidd, R.B., 1988. New sediment classification scheme for the Ocean Drilling Program. In Mazzullo, J., and Graham, A.G. (Eds.), Handbook for Shipboard Sedimentologists. ODP Tech. Note, 8:45-67.

McGuire, W.J., 1996. Volcano instability: a review of contemporary themes. In McGuire, W.J., Jones, A.P., and Neuberg, J. (Eds.), Volcano Instability on the Earth and Other Planets. Geol. Soc. Spec. Publ. London, 110:123.

McQuillin, R., Bacon, M., and Barclay, W., 1979. An Introduction to Seismic Interpretation: London (Graham and Trotman).

Middelburg, J.J., and De Lange, G.J., 1988. Geochemical characteristics as indicators of the provenance of Madeira Abyssal Plain turbidites: a statistical approach. Oceanol. Acta, 11:159-165.

Piper, D.J.W., 1978. Turbidite muds and silts on deepsea fans and abyssal plains. In Stanley, D.J., and Kelling, G. (Eds.), Sedimentation in Submarine Canyons, Fans and Trenches: Stroudsburg, PA (Dowden, Hutchinson and Ross), 163-175.

Rothwell, R.G., Pearce, T.J., and Weaver, P.P.E., 1992. Late Quaternary evolution of the Madeira Abyssal Plain, Canary Basin, NE Atlantic. Basin Res., 4:103-131.

Schmincke, H.-U., 1990. Geological Field Guide: Gran Canaria (4th ed.): Kiel, Germany (Pluto Press).

Schmincke, H.-U., Weaver, P.P.E., Firth, J.V., et al., 1995. Proc. ODP, Init. Repts., 157: College Station, TX (Ocean Drilling Program).

Schuttenhelm, R.T.E., Auffret, G.A., Buckley, D.E., Cranston, R.E., Murray, C.N., Shephard, L.E., and Spijkstra, A.E. (Eds.), 1989. Geoscience Inves- 
tigations of Two North Atlantic Abyssal Plains: The ESOPE International Expedition (Vols. 1 and 2): Luxembourg (CEC-Joint Research Centre), JRC Report EUR, 12331.

Searle, R.C., 1987. Regional setting and geophysical characterization of the Great Meteor East area in the Madeira Abyssal Plain. In Weaver, P.P.E., and Thomson, J. (Eds.), Geology and Geochemistry of Abyssal Plains. Spec. Publ. Geol. Soc. London, 31:49-70.

Sheriff, R.E. and Geldart, L.P., 1995. Exploration Seismology (2nd ed.): Cambridge (Cambridge Univ. Press).

Stow, D.A.V., and Shanmugam, G., 1980. Sequences of structures in finegrained turbidites: comparison of recent deep-sea and ancient flysch sediments. Sediment. Geol., 25:23-42.

Tolstoy, I., and Ewing, M., 1949. North Atlantic hydrography and the midAtlantic Ridge. Bull. Geol. Soc. Am., 60:1527-1540.

Van Hinte, J.E., 1978. Geohistory analysis: application of micropaleontology in exploration geology. AAPG Bull., 62:201-222.

Weaver, P.P.E., and Kuijpers, A., 1983. Climatic control of turbidite deposition on the Madeira Abyssal Plain. Nature, 306:360-363.
Weaver, P.P.E., and Rothwell, R.G., 1987. Sedimentation on the Madeira Abyssal Plain over the last 300,000 years. In Weaver, P.P.E., and Thomson, J. (Eds.), Geology and Geochemistry of Abyssal Plains. Geol. Soc. Spec. Publ. London, 31:71-86.

Weaver, P.P.E., Rothwell, R.G., Ebbing, J., Gunn, D., and Hunter, P.M., 1992. Correlation, frequency of emplacement and source directions of megaturbidites on the Madeira Abyssal Plain. Mar. Geol., 109:1-20.

Weaver, P.P.E., Searle, R.C., and Kuijpers, A., 1986. Turbidite deposition and the origin of the Madeira Abyssal Plain. In Summerhayes, C.P., and Shackleton, N.J. (Eds.), North Atlantic Palaeoceanography. Spec. Publ. Geol. Soc. London, 21:131-143.

Date of initial receipt: 1 July 1996

Date of acceptance: 24 February 1997

Ms 157SR-127 